\title{
First contribution to the bionomics of the pollen wasp Celonites fischeri Spinola, 1838 (Hymenoptera, Vespidae, Masarinae) in Cyprus
}

\author{
In memory of Friedrich W. Gess
}

\author{
Volker Mauss', Andreas Müller ${ }^{2}$ \\ I Staatliches Museum für Naturkunde, Abt. Entomologie, Rosenstein 1, D-70191 Stuttgart, Germany 2 ETH \\ Zürich, Institute of Agricultural Sciences, Biocommunication and Entomology, Schmelzbergstraße 9/LFO, CH- \\ 8092 Zürich, Switzerland \\ Corresponding author: Volker Mauss (volker.mauss@gmx.de)
}

Academic editor: Jack Neff| Received 4 May 2014 | Accepted 19 August 2014 | Published 26 September 2014

http://zoobank.org/13D25DFD-B7F6-42FF-9EF2-258E574DDCAA

Citation: Mauss V, Müller A (2014) First contribution to the bionomics of the pollen wasp Celonites fischeri Spinola, 1838 (Hymenoptera, Vespidae, Masarinae) in Cyprus. Journal of Hymenoptera Research 39: 119-153. doi: 10.3897/ JHR.39.7841

\begin{abstract}
Celonites fischeri was recorded from ten localities in various open, disturbed habitats in North-West Cyprus. The species is probably narrowly oligolectic exploiting exclusively flowers of Echium (Boraginaceae) as the sole pollen and nectar source. Females perform a pollen collecting strategy hitherto unknown in pollen wasps; they ingest pollen from fresh anthers of Echium flowers that have just started to open by forcing their head into the only slightly opened corolla. Males patrol along Echium plants in search for females. Mating was mainly observed at Echium flowers but also occurred in the area of a male sleeping aggregation. The aerial nest, consisting of $2-5$ earthen cells sometimes covered with an additional thin layer of earth, is attached to stones or plants. Nest building and soil collection behaviour are described and an ethogram of a nesting female observed during three consecutive days is given. Males form sleeping aggregations at particular sites that are continuously used over at least eleven consecutive nights, even though the size of the male groups may vary from day to day. During sleeping, the males characteristically curl their bodies around withered stems.
\end{abstract}

\section{Keywords}

Palaearctic, Echium, flower association, oligolecty, mating behaviour, nest construction, sleeping aggregation

Copyright Volker Mauss, Andreas Müller. This is an open access article distributed under the terms of the Creative Commons Attribution License (CC BY 4.0), which permits unrestricted use, distribution, and reproduction in any medium, provided the original author and source are credited. 


\section{Introduction}

The knowledge of the bionomics of Palaearctic species of the pollen wasp genus $\mathrm{Ce}$ lonites is still very limited. Hitherto, forty-six species of Celonites have been recorded in the Palaearctic region (Carpenter 2001; Gusenleitner 2002, 2007, 2012; Mauss 2013), but detailed bionomical information has been published only for Celonites abbreviatus (Villers, 1789). Studies on this species refer to mating (Mauss 2006), nesting behaviour (Lichtenstein 1869; Ferton 1901, 1910; Bellmann 1984, 1995), flower association and flower visiting behaviour (Bequaert 1940; Schremmer 1959; Blüthgen 1961; Bellmann 1995; Müller 1996; Mauss 2006) and male sleeping aggregations (Amiet and Mauss 2003). Further information is restricted to a few flower visiting records for Celonites mayeti Richards, 1962, C. andreasmuelleri Mauss, 2013, C. afer Lepeletier, 1841, one species of the C. phlomis-group and six species of the subgenus Eucelonites (Bequaert 1940; Richards 1962; Gusenleitner 1973; Mauss 2013). Moreover, Lichtenstein (1875) published a short and fragmentary description of a nest of $C$. mayeti (erroneously named as $C$. fischeri).

Bionomical information about Celonites fischeri is lacking, despite a short, unconfirmed note of Bingham (1898), who stated that this species had been reared from cylindrical mud nests in Aden (Yemen). The geographic range of $C$. fischeri extends over North Africa, Cyprus, the Middle East and the Arabian Peninsula (Richards 1962, 1984; Carpenter 2001). Together with $C$. afer the species belongs to the $C$. fischeri-complex. The $C$. fischeri-complex and the C. abbreviatus-complex form the C. abbreviatus-group within the subgenus Celonites s. str. (Mauss 2013). The C. fischeri-complex is characterized by a normal facial pilosity thereby differing from species of the closely related $C$. abbreviatuscomplex, which are equipped with a specialised pollen collecting apparatus on the frons consisting of knobbed setae (Mauss 2013). In C. abbreviatus, these knobbed setae serve to remove pollen from the nototribic anthers of various species of Lamiaceae (Schremmer 1959; Bellmann 1995; Müller 1996; Mauss 2006). Other members of the C. abbreviatuscomplex like $C$. mayeti and $C$. andreasmuelleri were also observed to visit flowers of this plant family (Bequaert 1940; Mauss 2013). Due to this difference in facial pilosity, host plant choice and flower visiting behaviour are expected to differ between the members of the two closely related Palaearctic species complexes of the C. abbreviatus-group.

The aim of this study is to perform a detailed investigation of flower association and flower visiting behaviour, mating, female brood care and male behaviour in $\mathrm{Ce}$ lonites fischeri and to compare the biology of this species with that of other members of the C. abbreviatus-group, some Ethiopian species of Celonites as well as other aerial nesting members of the Masarini.

\section{Material and methods}

Investigations were carried out from 20 May to 30 May 2013 in the vicinity of Paphos in north-western Cyprus. The study area has a Mediterranean climate with hot, dry 
summers and mild, rainy and rather changeable winters (Meteorological Service 2014). The average annual precipitation in Paphos is about $370 \mathrm{~mm}$ (Baier et al. 2009). The mean temperature in the hottest (August) and coldest month (February) is $26^{\circ} \mathrm{C}$ and $13^{\circ} \mathrm{C}$, respectively (Flint and Stewart 1992). During the study period, the weather was mainly sunny and warm with maximum air temperatures above $25^{\circ} \mathrm{C}$, reaching $30{ }^{\circ} \mathrm{C}$ on three days (suboptimal conditions with clouds or haze predominated in the afternoon of 24 May and in the morning of 26 May and 29 May). On 22 May and 24 May, Celonites fischeri was searched for systematically in the vicinity of Paphos by checking promising sites with large Echium populations. Geographic coordinates (WGS 84) were measured using a Garmin GPS 12.

Celonites fischeri was found at 10 localities [I Kato Paphos 34\%44.495'N

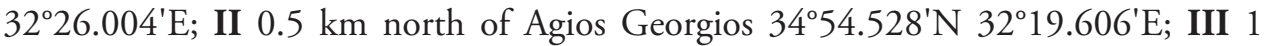
$\mathrm{km}$ south-east of Coral Bay $34^{\circ} 50.582^{\prime} \mathrm{N} 32^{\circ} 23.232^{\prime} \mathrm{E}$; IV $1.5 \mathrm{~km}$ south-east of Drousia $34^{\circ} 57.683^{\prime} \mathrm{N} 32^{\circ} 24.834^{\prime} \mathrm{E}$; V Prodromi $35^{\circ} 01.779^{\prime} \mathrm{N} 32^{\circ} 24.798^{\prime} \mathrm{E}$; VI $3 \mathrm{~km}$ south-west of Prodromi $35^{\circ} 00.760^{\prime} \mathrm{N} 32^{\circ} 23.584^{\prime} \mathrm{E}$; VII $2 \mathrm{~km}$ south-west of Nikoklia $34^{\circ} 43.007^{\prime} \mathrm{N} 32^{\circ} 32.956^{\prime} \mathrm{E}$; VIII $1 \mathrm{~km}$ north of Choletria $34^{\circ} 46.462^{\prime} \mathrm{N} 32^{\circ} 36.448^{\prime} \mathrm{E}$; IX $0.5 \mathrm{~km}$ south-south-west of Praitori $34^{\circ} 50.672^{\prime} \mathrm{N} 32^{\circ} 44.500^{\prime} \mathrm{E}$; X $0.5 \mathrm{~km}$ south of Pachna $34^{\circ} 46.120^{\prime} \mathrm{N} 32^{\circ} 47.334^{\prime} \mathrm{E}$ ]. Most studies were conducted at locality II at the northern periphery of Agios Georgios, a disturbed Phrygana fragment of about 900 $\mathrm{m}^{2}$, which was irregularly grazed by goats and rarely also by donkeys (Fig. 3). The area was delimited in the east by large thick bushes and in the south by a small track and an adjoining banana plantation. To the west and the north, the area was separated from the adjacent costal Phrygana of the Akámas Peninsula by two small tarred roads. In the area, 26 richly flowering patches of Echium angustifolium Mill. (Boraginaceae) were present varying in size between 0.25 to $2 \mathrm{~m}^{2}$ (Fig. 46). In addition, fifteen other plant species were in flower [Asteraceae: Calendula arvensis L., Carduus nutans L., Centaurea hyalolepis Boiss., Chrysanthemum coronarium L., Pallenis spinosa (L.) Cass, Scolymus hispanicus L., Asteraceae spec.; Boraginaceae: Heliotropium hirsutissimum Grau.; Brassicaceae: Sisymbrium irio L.; Fabaceae: cf. Lotus spec.; Lamiaceae: Ajuga chamaepitys (L.) Schreb. palaestina (Boiss.) Bornm., Teucrium micropodioides Rouy; Malvaceae: Malva cretica Cav.; Primulaceae: Anagallis foemina Mill.; Ranunculaceae: Delphinium peregrinum L.].

For all documentations of observations the local time (= Greenwich Mean Time $+3 \mathrm{~h}$ ) was used. Sunrise was approximately at $5 \mathrm{~h} 35$, sun's zenith at $12 \mathrm{~h} 45$ and sunset at $19 \mathrm{~h} 50$. Time intervals were measured using a digital stop-watch. Observations were made with a close-up binocular (Pentax Papilio $8.5 \times 21$ ) and documented by using a Canon EOS camera with a $180 \mathrm{~mm}$ or $100 \mathrm{~mm}$ macro-lens (scale up to $1: 1$, resolution 18 mega pixel) and macro flash-lights.

Specimens of all plant species flowering at locality II were collected and preserved dried. The material was placed in the herbarium of the Staatliches Museum für Naturkunde Stuttgart (Herbarium STU). The plant taxa were identified following Meikle (1977-1985) and Tutin et al. (1964-1980). Flower preferences of imagines were studied by counting the number of sightings (= first observations) of flower visiting 


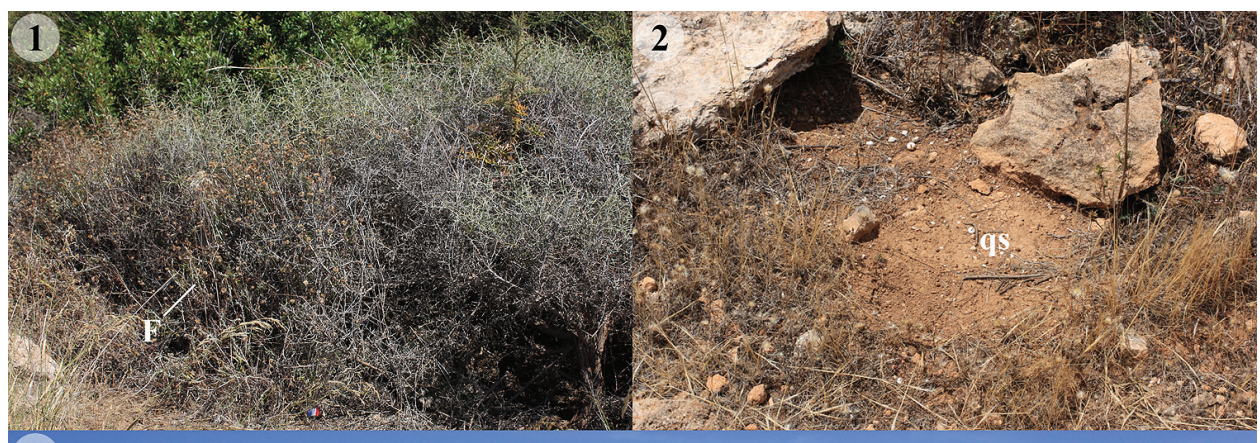

3
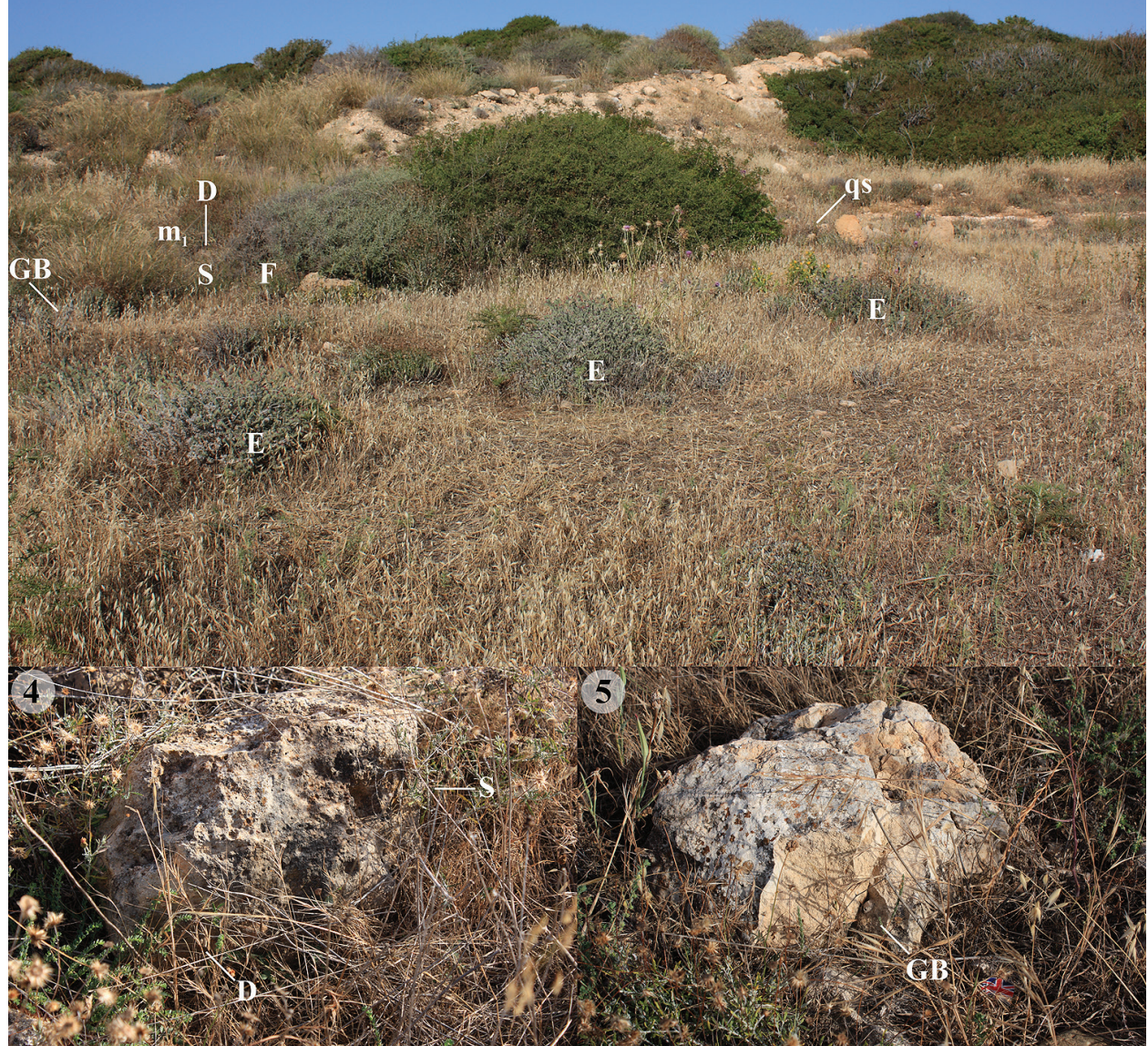

Figures I-5. Habitat of Celonites fischeri at locality II $0.5 \mathrm{~km}$ north of Agios Georgios, Cyprus: I Nest site of nest $\mathrm{F}$ attached to a dwarf shrub (Asteraceae) $\mathbf{2}$ Bare area in the centre used by females of $C$. fischeri as a quarry site (qs) 3 Disturbed Phrygana (viewed from the south-west; with patches of Echium angustifolium (E), sites of three nests (D, F, S), quarry site (qs) and male sleeping aggregation $m_{1}$ ) 4 Nest D and nest $S$ attached to the same stone (viewed from the north, nest $S$ not visible behind the side of the stone) 5 Nest GB attached to stone. 
individuals while walking randomly across the area at all localities (total investigation time $18.25 \mathrm{~h}$ ). Flower visiting behaviour of Celonites fischeri at Echium angustifolium was investigated at various patches of this plant at the localities I and II for $15 \mathrm{~h}$ in total. Pollen samples from two brood cell provisions of nest $\mathrm{F}$ (see below) from locality II were prepared using the method outlined by Westrich and Schmidt (1986). In addition, pooled pollen samples from four localities (II, III, VI and IX) were prepared each with pollen from the crops of five females previously fixed in Duboscq-Brasil solution (Romeis 1989). The different pollen types were ascertained under a light microscope at magnifications of $400 \times$ or $1000 \times$ and determined to generic level with the aid of a reference collection consisting of pollen samples of 500 mainly Mediterranean plant species.

The behaviour of a female at one of the nests (nest F; see below) was continuously investigated from 27 May until 30 May except for the individual's resting period during the night (total observation time $27.5 \mathrm{~h}$ ). Spatial and temporal behavioural patterns were reconstructed in more detail by analysis of sequences of photographies repeatedly taken during the observation period. Activities inside the cell were observed with the aid of a magnifying hand mirror.

The nests were marked in the field with little ice-cream national flags and named after the country code of the flag used (Fig. 5). Nest GB was removed on 26 May, nest $\mathrm{S}$ and D on 27 May, and nest F on 30 May. In the field, cell dimensions were measured using a strip of millimetre paper (accuracy $1 \mathrm{~mm}$ ). The brood cells were opened on June 1 and investigated under a stereomicroscope (Wild M3, magnification up to $40 \mathrm{x}$, ocular micrometer with a maximum accuracy of $0.024 \mathrm{~mm}$ ). The remnants of the nests as well as dry specimens of males and females from all localities were placed in the collection of Volker Mauss.

Behaviour and activity of males at sleeping aggregations were recorded at locality I both by point observations and during random searching on 20 May between $15 \mathrm{~h} 00$ and $17 \mathrm{~h} 30$, and at locality II by short observations on eight days. The number of males in each group (defined as all males sleeping together on the same stem end for a night) and the number of male groups were systematically counted in the evening, when male activity had completely stopped and all males remained motionless in sleeping position (at locality I from 20 to 30 May between 19h20 and 20h00; at locality II on 21, 23 and from 25 to 30 May between $17 \mathrm{~h} 40$ and $19 \mathrm{~h} 00$ ).

\section{Results}

\section{Habitat}

Celonites fischeri was found in various open and disturbed areas, including Phrygana fragments, coastal dunes, abandoned building areas and olive groves, as well as road sides. The localities were situated at altitudes between $10 \mathrm{~m}$ and $660 \mathrm{~m}$ above sea level. They were characterized by a considerable quantity of Echium angustifolium. Open water sources were always lacking. 


\section{Flower association}

During random searching, all 46 sightings of flower visiting females and all 8 sightings of flower visiting males of Celonites fischeri were exclusively recorded at Echium angustifolium. Likewise, 68 females and 13 males recorded during point observations visited flowers of $E$. angustifolium. Visits to flowers of other plant species were not observed.

Both males and females showed two different types of behaviour at the flowers. The first behaviour served presumably for nectar uptake. The wasp alighted on the upper margin of the corolla and moved quickly head first deep into the corolla tube so that only distal parts of the metasoma remained visible in the flower opening (Figs 6, 8). Within the flower, the ventral side of the wasp was always orientated towards the upper wall of the corolla and its dorsal side towards the filaments and the style (Fig. 8). The wasp stayed in this position for a moment before it moved backwards out of the corolla tube and flew off. On a few occasions, when the wasp was leaving the flower, distal parts of the protruded proboscis were visible for a moment before the proboscis was completely retracted, indicating nectar uptake (Fig. 7). The median duration of nectar uptake by females was $3.2 \mathrm{~s}$ (range 1.6-9.8 s, $\mathrm{n}=18$ ). Nectar uptake was observed only at completely open flowers in full blossom. The second behaviour served apparently for pollen collection. The wasp alighted on the corolla and worked an anther with mandibles and maxillae (Figs 9, 13), while the proboscis remained retracted. At the same time, the fore legs made brushing movements from the anther towards the mouth and were repeatedly moved between the moving mouthparts. During the whole process the wasp held on only with its mid and hind legs with the meso- and metasoma remaining outside the corolla. The median duration of pollen uptake by females was $79.6 \mathrm{~s}$ (range 5.1-229.9 s, $\mathrm{n}=15$ ), which is significantly longer than the time for nectar uptake (Mann-Whitney Test: $\mathrm{p}(2$-tailed $)<0.001)$. Pollen uptake by females was recorded at flowers with open (Fig. 13), half opened (Fig. 12) and only slightly opened corollae (Fig. 11), depending on the age of the flowers. In the latter case, the females forced their head into the only slightly opened corolla of flowers that had just started to open (Fig. 10,11). The median duration of pollen uptake by the females did not differ significantly between flowers in different phases of corolla opening (Fig. 47; Kruskal-Wallis Test: $\mathrm{Chi}^{2}=0.72, \mathrm{df}=2$, $\mathrm{p}=0.70$ ). On a single occasion a male was also observed to take up pollen from a flower with only slightly opened corolla tube while all other visits took place at open flowers.

Females were often observed to fly slowly past many flowers within an Echium patch before finally alighting on a particular flower where they started to take up pollen. During such an "inspection flight", a female sequentially approached flowers, but shortly before she came into contact with the corolla she changed the course and directed her flight towards another flower where the whole process started anew. Inspection flights were infrequently interrupted by perching on twigs or dry leaves, which was accompanied by cleaning behaviour in two instances. Foraging females were occasionally observed to switch from nectar uptake to pollen uptake or vice versa during a single flower visit as well as on consecutive visits to different flowers.

The crop content of all females investigated and the two brood cell provisions from the same nest consisted exclusively of pollen from Echium (more than 99\%). 


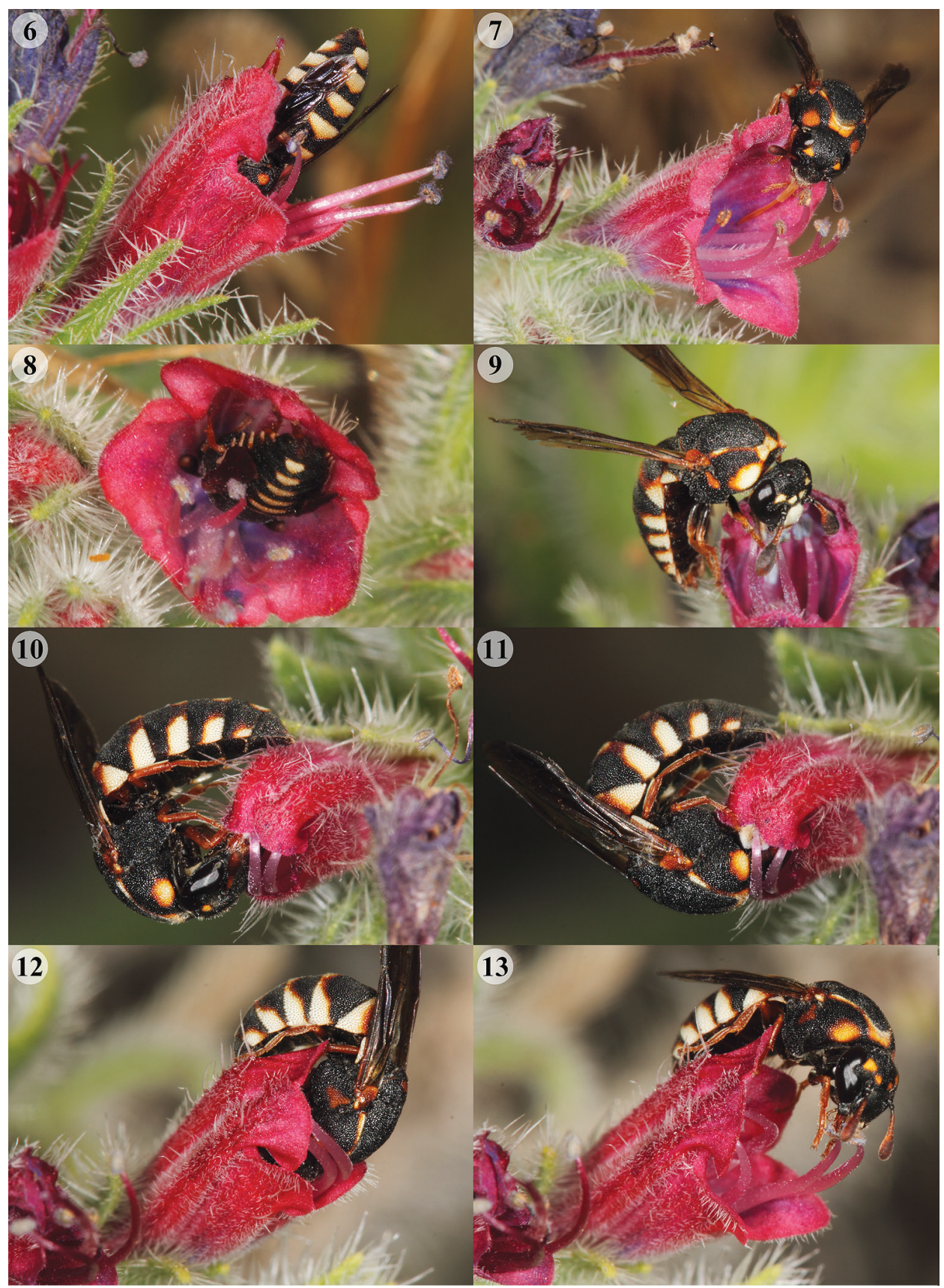

Figures 6-13. Flower visiting behaviour of Celonites fischeri at Echium angustifolium: 6 Female entering flower head first for nectar uptake $\mathbf{7}$ Female leaving flower after nectar uptake with proboscis still protruding 8 Male deeply inside corolla tube during nectar uptake 9 Male feeding on pollen directly from an anther I0-I I Female taking up pollen from flower with only slightly opened corolla tube $\mathbf{I 0}$ from anther accessible from outside I I after forcing her head into the corolla tube from anthers inside the corolla tube I 2-13 Females taking up pollen from the same flower at different stages of corolla opening $\mathbf{2}$ corolla half open $\mathbf{3} 9.5$ min later corolla completely open. 


\section{Mating}

Mating behaviour was observed both at flowering patches of Echium angustifolium and in the area of a male sleeping aggregation.

Males were frequently observed to patrol in a constant flight slightly above the Echium plants, sporadically interrupted by perching on inflorescences or on dry, horizontal stems near Echium plants (Fig. 21). Patrolling males sometimes approached each other over a short distance, but then continued their flights without any further interaction. On one occasion, two patrolling males flew towards each other, hovered face to face at a distance of about $1 \mathrm{~cm}$ and soared up in this position for approximately $5 \mathrm{~cm}$, before they flew off in different directions. Patrolling males were observed several times to pounce on a flower visiting or perching male and, in a few incidents, they performed mating movements (Fig. 19) before flying off.

The behavioural sequence during copulation can be subdivided into three phases: 1. initiation, 2. insertion, 3. separation. At flowers, initiation always started by a patrolling male pouncing on a flower visiting female. In 12 out of a total of 16 cases, this was unsuccessful, since the female fell to the ground or flew off, remained on the flower without further interaction with the male or the male turned away before reaching the female (Fig. 14). In four cases, pouncing was successful and initiation behaviour was continued. After alighting on the dorsal mesosoma of the female the male held on to it (Fig. 15) and orientated his body axis parallel to hers. This resulted in a position, in which the head of the male was slightly anterior to the female's head with the male antennae orientated downwards and his fore legs placed on frontal parts of the female's head (Fig. 16). Then the male protruded the distal end of his proboscis at least for a short moment, raised his antennae and moved backwards on the back of the female (Fig. 20). During this process, the male antennae were orientated obliquely upwards and the male genitalia were already visible in the opening of the genital chamber. Finally, the head of the male was positioned above the posterior half of the female mesosoma and the basal parts of his fore legs were placed over the base of her wings and tegulae along with the fore tarsi on the sides of her mesosoma (Fig. 17). His mid and hind legs held laterally on to the anterior segments of her metasoma. The posterior end of the male metasoma was well behind the tip of the metasoma of the female (Fig. 18). The male genital chamber remained open and the genitalia were somewhat protruded. The mouthparts of the male were retracted with one exception when the distal end of the proboscis was still in a protruded position. The female usually continued pollen uptake. During the following insertion phase the male genitalia were inserted into the female genital chamber. This was observed only once with certainty at flowers and lasted for about $10 \mathrm{~s}$. Separation was a short process in which the male genitalia were removed from the genital chamber of the female and both partners flew off directly. On two occasions it was observed that a second male alighted on the back of a copulating male (during initiation and insertion respectively) for a few seconds (Fig. 20).

Mating behaviour away from flowers was only observed once: At the male sleeping aggregation $\mathrm{m}_{2}$ on 21 May at $15 \mathrm{~h} 49$ a female alighted on a fine, dry twig where 


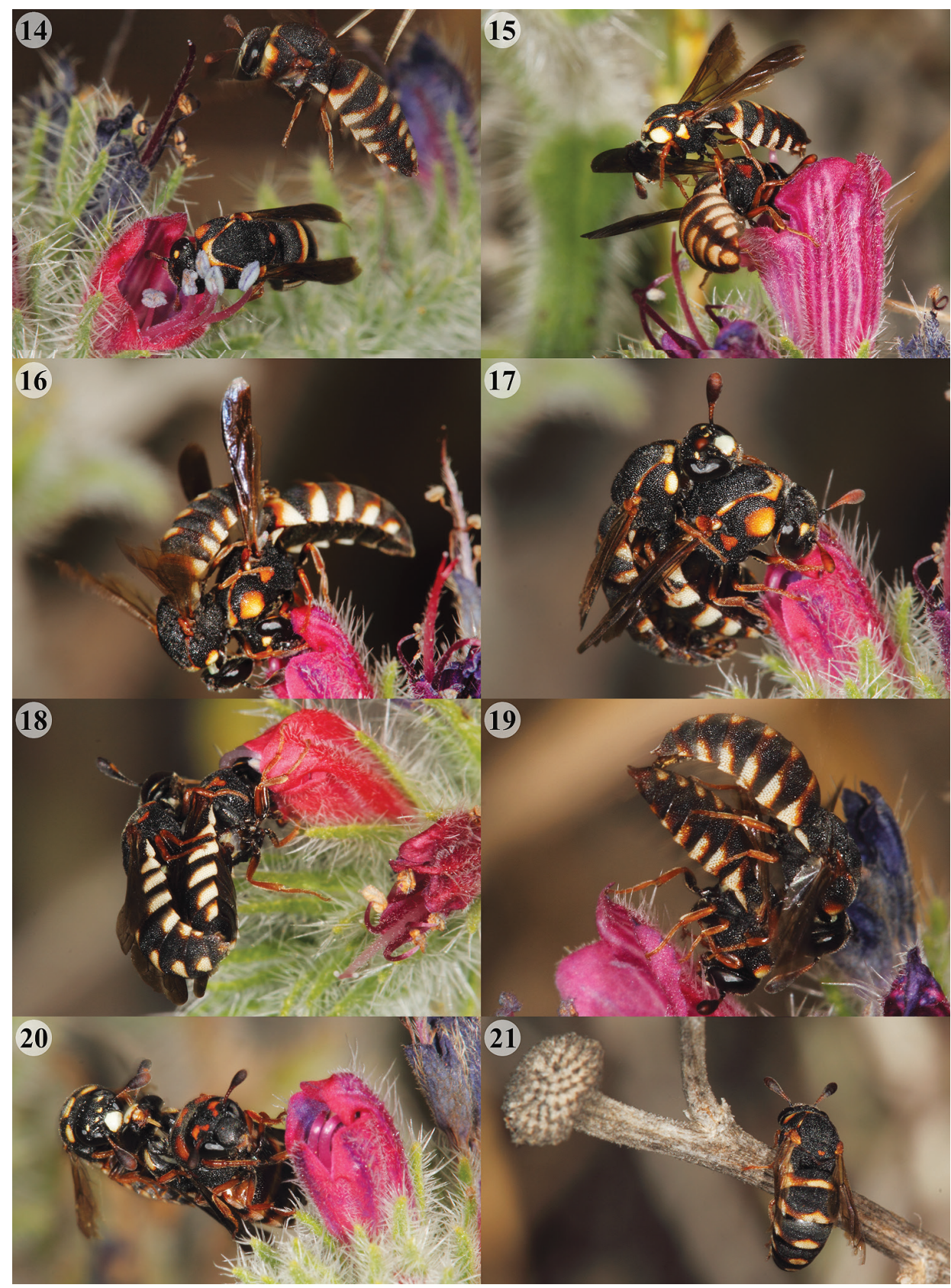

Figures 14-2I. Mating behaviour of Celonites fischeri: 14 Pouncing male turning off before reaching a flower visiting female $\mathbf{I 5}$ Male alighting on the mesosoma of flower visiting female, trying to hold on 16 Anterior position of the male during initiation, in which his head is a little anterior to the head of the female $\mathbf{I 7}$ Posterior position of the male during initiation, in which the head of the male is positioned above the posterior half of the mesosoma of the female $\mathbf{1 8}$ Male in posterior position during initiation, trying to insert genitalia into the genital chamber of the female. Note protruded male proboscis 19 Male performing mating movements after pouncing on a perching male $\mathbf{2 0}$ Male alighting on a pair in initiation phase. Note protruded proboscis of primary male $\mathbf{2} \mathbf{I}$ Male perching on dry stem of perennial herbaceous plant. 
she remained for $7 \mathrm{~min}$, while males were absent. In the beginning the female folded her wings under her metasoma. Later on she slightly opened her wings and spread her antennae. Then a flying male appeared and alighted directly on the mesosoma of the female, moved backwards on her back and inserted his genitalia into her genital chamber for $8.1 \mathrm{~s}$ before the partners separated and flew off.

\section{Female brood care}

Nest structure: Four nests were discovered at locality II (Table 1). All nest sites were less than $5 \mathrm{~m}$ away from patches of Echium angustifolium (Fig. 46). Three nests (GB, D and $S$ ) were attached to medium sized stones less than $10 \mathrm{~cm}$ above the ground. The nests were on oblique to nearly vertical lateral parts of the stones exposed to the west or north and were more or less hidden by vegetation (Fig. 4, 5). A fourth nest (F) was placed approximately $25 \mathrm{~cm}$ above the ground on a narrow, almost vertical stem about $10 \mathrm{~cm}$ inside of a dwarf shrub of the family Asteraceae, which was situated on the south-western margin of a patch of bushes (Fig. 1).

The nests were made of fine clayey soil with a small but variable proportion of tiny stones. The nests consisted of 2.5 cells in the median $(n=4)$ (Table 1). All the cells were orientated almost vertically with the opening directed towards the ground, but the arrangement of the cells was variable. In three nests, the cells were abutted only longitudinally (Figs 24, 25). In nest F, the third cell was also attached to the first cell longitudinally but the second cell was constructed with its closed end abutting the seal of the completed first cell resulting in a linear arrangement of these cells (Fig. 26). A nest covering was only present in nest GB (Fig. 22). The covering consisted of a smooth, thin layer of the same fine clayey earth as the brood cells and covered the cells completely. The material of the covering could be separated from the cell walls without difficulty indicating that it had been applied after the cells had been finished. The covering was only attached to the outer curves of the cells and to the adjacent substrate thus stretching over medial and lateral hollow spaces between the cells and the cell walls and the underlying stone respectively (Fig. 23).

The brood cells were cylindrical, rounded at the closed (basal) and truncate at the open (apical) end (Fig. 25). The median dimensions of the cells were: length of completed cells $10.5 \mathrm{~mm}(\mathrm{n}=10)$; outer diameter $4.4 \mathrm{~mm}(\mathrm{n}=4)$; and inner diameter at the cell opening $3.5 \mathrm{~mm}(\mathrm{n}=9)$ (Table 2). The median thickness of the cell wall was $0.29 \mathrm{~mm}(\mathrm{n}=11)$, becoming somewhat wider at the basal end of the cell. The outer cell surface showed a distinct "fish scale" pattern while the inner surface was smooth. The cell seal was positioned about $1 \mathrm{~mm}$ inwards from the edge of the cell opening. The thickness of the seal varied slightly over its diameter and measured in the median $0.23 \mathrm{~mm}(\mathrm{n}=8)$ at the thinnest part. Sealed cells of old nests mainly had a large frontal or lateral opening that covered the apical third of the cell and had probably been made by an emerging imago of Celonites fischeri (Figs 22, 25, Table 2).

Brood cell content: The content of the brood cells is summarized in Table 2. 


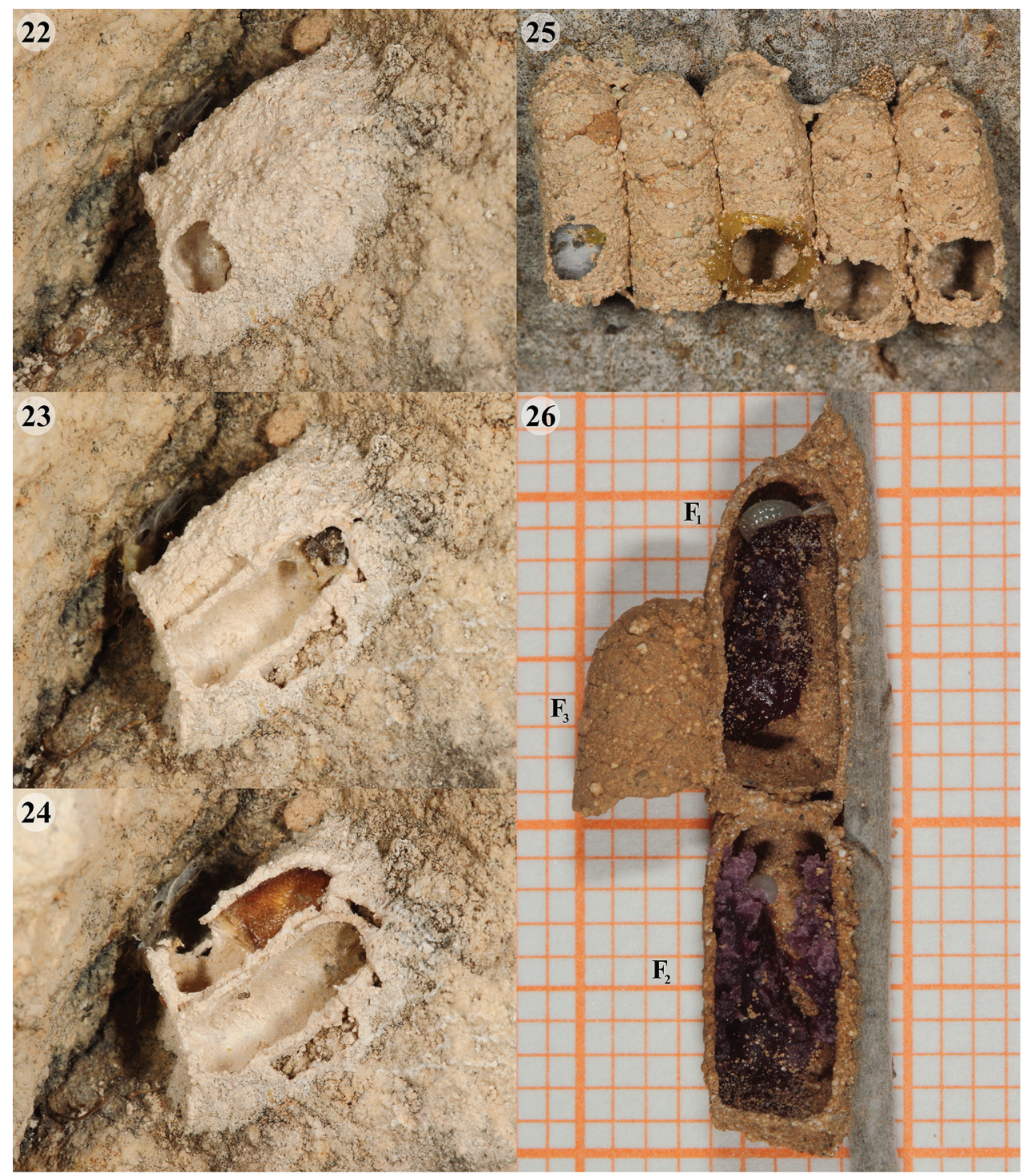

Figures 22-26. Nest structure of Celonites fischeri: 22-24 Nest GB 22 Original condition on 26 May with frontal emergence hole probably made by $C$. fischeri. 23 Nest covering partly removed to show hollow spaces underneath; cell $\mathrm{GB}_{1}$ opened containing meconium of $C$. fischeri at basal end $24 \mathrm{Cell}_{\mathrm{GB}}$ opened, showing brittle brown cocoon of unidentified holometabolic insect in basal half and small emergence hole apical in the cell wall 25 Nest $S$ on 27 May. Cells $S_{1}, S_{3}, S_{4}, S_{5}$ (ordered from the left) with frontal emergence holes probably made by $C$. fischeri $\mathbf{2 6}$ Nest $\mathrm{F}$ on 1 June after dissection of cells $\mathrm{F}_{1}$ and $\mathrm{F}_{2}$ (cell content summarized in Table 2).

The provision was a purple, firm, but somewhat viscous pollen mass with shining surface. Contact of the provision with the cell walls was variable: In cell $\mathrm{F}_{1}$ the surface of the pollen mass was characteristically papillated (Fig. 26), so that it barely touched 
Table I. Parameters of four nests of Celonites fischeri recorded at locality II $0.5 \mathrm{~km}$ north of Agios Georgios, Cyprus.

\begin{tabular}{c|c|c|c|c|c|c|c|c}
\hline Nest & Condition & $\begin{array}{c}\text { Height above } \\
\text { ground } \\
(\mathbf{m m})^{1}\end{array}$ & $\begin{array}{c}\text { Orientation } \\
\text { to the } \\
\text { North }\left(^{\circ}\right)\end{array}$ & Nest substrate & $\begin{array}{c}\text { Inclination of } \\
\text { nest substrate }\left(^{\circ}\right)\end{array}$ & $\Sigma$ cells & $\begin{array}{c}\text { Contact } \\
\text { between } \\
\text { adjacent cells }\end{array}$ & $\begin{array}{c}\text { Nest } \\
\text { covering }\end{array}$ \\
\hline GB & old & 43 & 20 & $\begin{array}{c}\text { stone (base } 38 \times 31 \\
\text { cm, height } 19 \mathrm{~cm})\end{array}$ & 60 & 2 & longitudinal & present \\
\hline D & old & 77 & 20 & $\begin{array}{c}\text { stone }(\text { base } 40 \times 29 \\
\text { cm, height } 24 \mathrm{~cm})\end{array}$ & 85 & 2 & longitudinal & absent \\
\hline $\mathbf{S}$ & old & 90 & 280 & $\begin{array}{c}\text { stone (base } 40 \times 29 \\
\text { cm, height } 24 \mathrm{~cm})\end{array}$ & 95 & 5 & longitudinal & absent \\
\hline F & $\begin{array}{c}\text { under } \\
\text { construction }\end{array}$ & 243 & 70 & $\begin{array}{c}\text { plant (narrow stem } \\
\text { of Asteraceae scrub) }\end{array}$ & 100 & 3 & $\begin{array}{c}\text { linear or } \\
\text { longitudinal }\end{array}$ & absent \\
\hline
\end{tabular}

${ }^{1}$ measured from the lowest part of the nest

the cell walls. In cell $\mathrm{F}_{2}$ the provision broadly adhered to the wall and apparently moistened it. However, this could have been an artefact, since the cell had to be removed and transported only a few hours after provisioning had been completed. The outer cell surface appeared to be dry when the cell was removed but was wet two days later, when the cell was opened, suggesting an artificial situation.

The egg of Celonites fischeri from cell $\mathrm{F}_{2}$ was whitish, curved and measured 1.88 $\mathrm{mm}$ in length. It was situated on top of the provision close to the basal end of the cell (Fig. 26). Remnants of fibrous material were attached to one pole of the egg indicating that it had been fixed to the original cell wall before this had been removed during the dissection of the cell. In the same way the small larva from cell $\mathrm{F}_{1}$ was also situated basally on top of the pollen mass, where it fed on the provision (Fig. 26). As in the egg there was some light fibrous material adhering to the posterior end of the larva that was distally fixed to the cell wall. The cocoon of $C$. fischeri consisted of whitish to yellowwhitish shining threads thinly covering the inner cell walls and the seal (Fig. 23). The threads became more sparse towards the basal end of the cell and in $50 \%$ of the cases $(n=6)$ threads were completely lacking at the basal end of the cell. The meconium was situated at the basal end more or less inside the cocoon. The cocoon threads were more brownish in this part of the cell indicating the secretion of a fluid component during the discharge of the meconium (Fig. 24). The solid fraction of the meconium comprised about 50 little, spherical, blackish packs containing pollen exines. The packs were loosely connected to each other by short threads.

Behaviour at the nest. The temporal pattern of the behaviour of the focally observed female at nest $\mathrm{F}$ is summarized in Fig. 48. The behavioural sequence during brood cell preparation can be subdivided into four phases: 1 . cell building, 2 . oviposition, 3 . provisioning, 4. sealing.

At the beginning of the construction of a new brood cell, when already one or more cells had been constructed, the female alighted without a soil pellet on the stem just below the nest. Then she walked upwards and downwards, randomly across the cell(s) and also back on the stem again for approximately 1-2 min. Finally she 


\begin{tabular}{|c|c|c|c|c|c|}
\hline 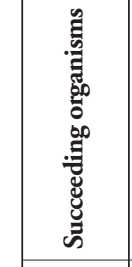 & 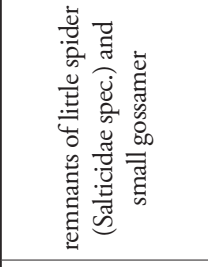 & & 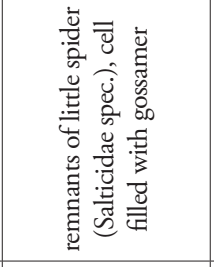 & & 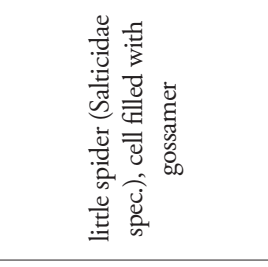 \\
\hline 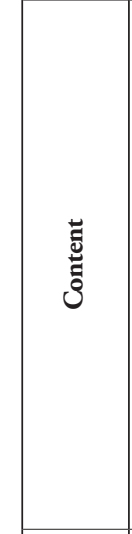 & 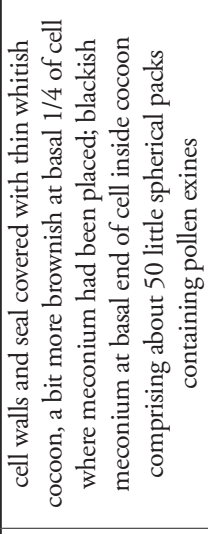 & 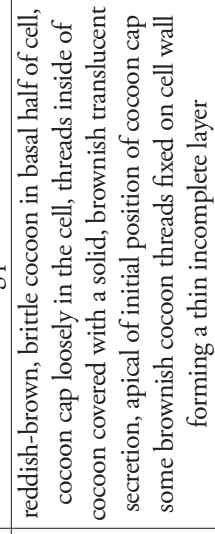 & 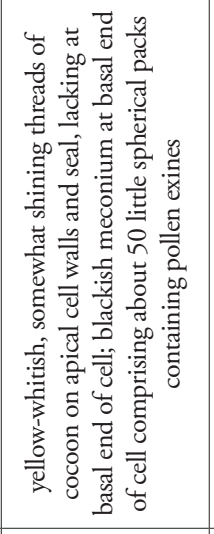 & & 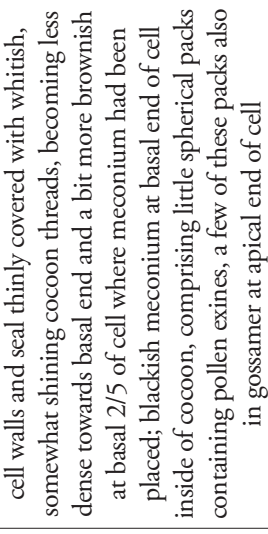 \\
\hline 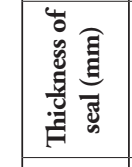 & & & $\stackrel{\sharp}{3}$ & & $\stackrel{\longleftarrow}{0}$ \\
\hline 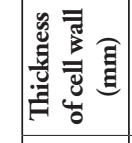 & $\stackrel{\infty}{0}$ & $\tilde{n}$ & ָิ & חֶ. & $\stackrel{\sharp}{3}$ \\
\hline 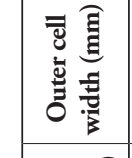 & & & $\underset{+}{*}$ & & \\
\hline 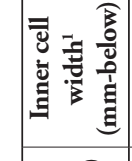 & $n$ & $n$ & $n$ & $m$ & $n$ \\
\hline 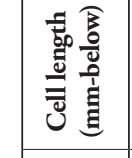 & 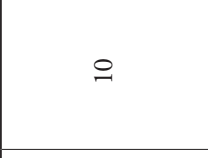 & $a$ & $\stackrel{ }{ }$ & $\checkmark$ & $\stackrel{ }{-}$ \\
\hline ن̃ & 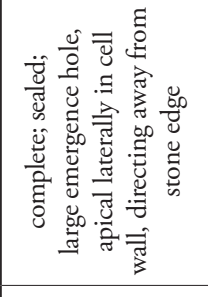 & 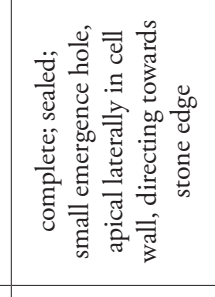 & 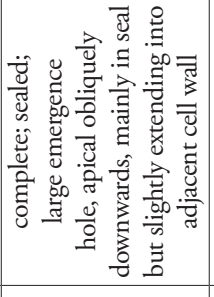 & 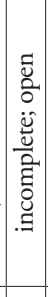 & 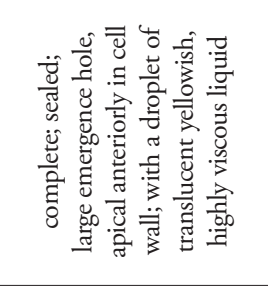 \\
\hline$\overline{\mathrm{U}}$ & $\neg$ & $N$ & - & N & - \\
\hline 峞 & \multicolumn{2}{|c|}{ 芯 } & D & & $\infty$ \\
\hline
\end{tabular}




\begin{tabular}{|c|c|c|c|c|}
\hline 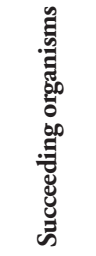 & 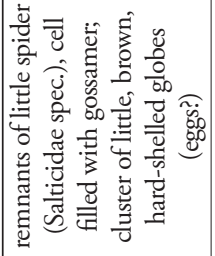 & 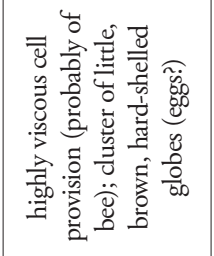 & & \\
\hline $\begin{array}{l}\vec{E} \\
\overrightarrow{0}\end{array}$ & & 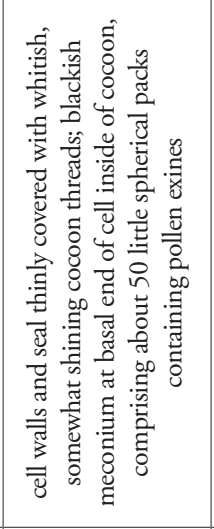 & 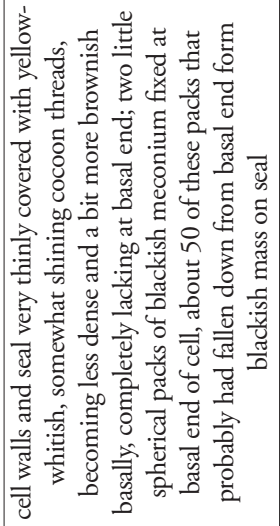 & 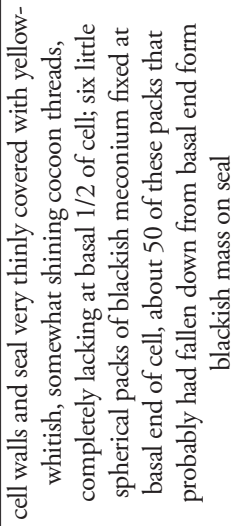 \\
\hline 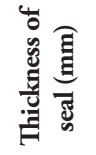 & $\stackrel{\pi}{0}$ & స̃ & $\stackrel{0}{0}$ & $\stackrel{\varpi}{3}$ \\
\hline 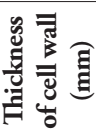 & ָิ & 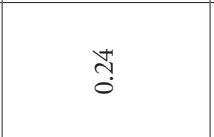 & 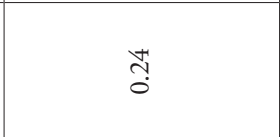 & તิ \\
\hline 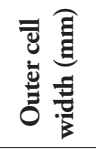 & & & & \\
\hline 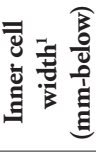 & $n$ & $n$ & $n$ & $n$ \\
\hline 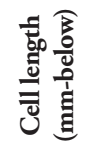 & $\stackrel{-}{ }$ & $=$ & $\exists$ & $=$ \\
\hline ن气 & 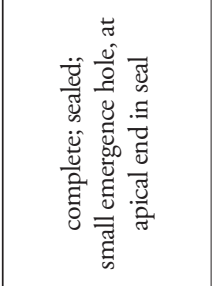 & 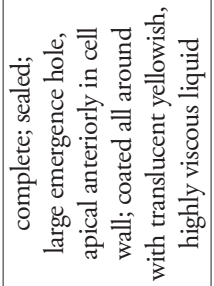 & 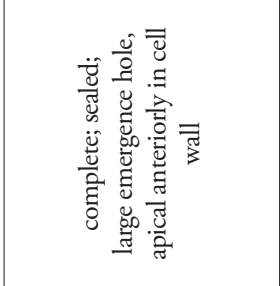 & 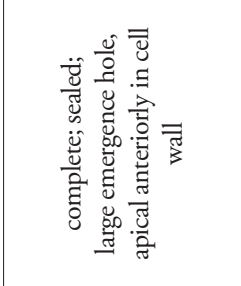 \\
\hline$\overline{\mathrm{J}}$ & $\sim$ & $n$ & 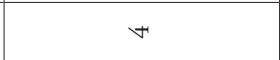 & $n$ \\
\hline
\end{tabular}




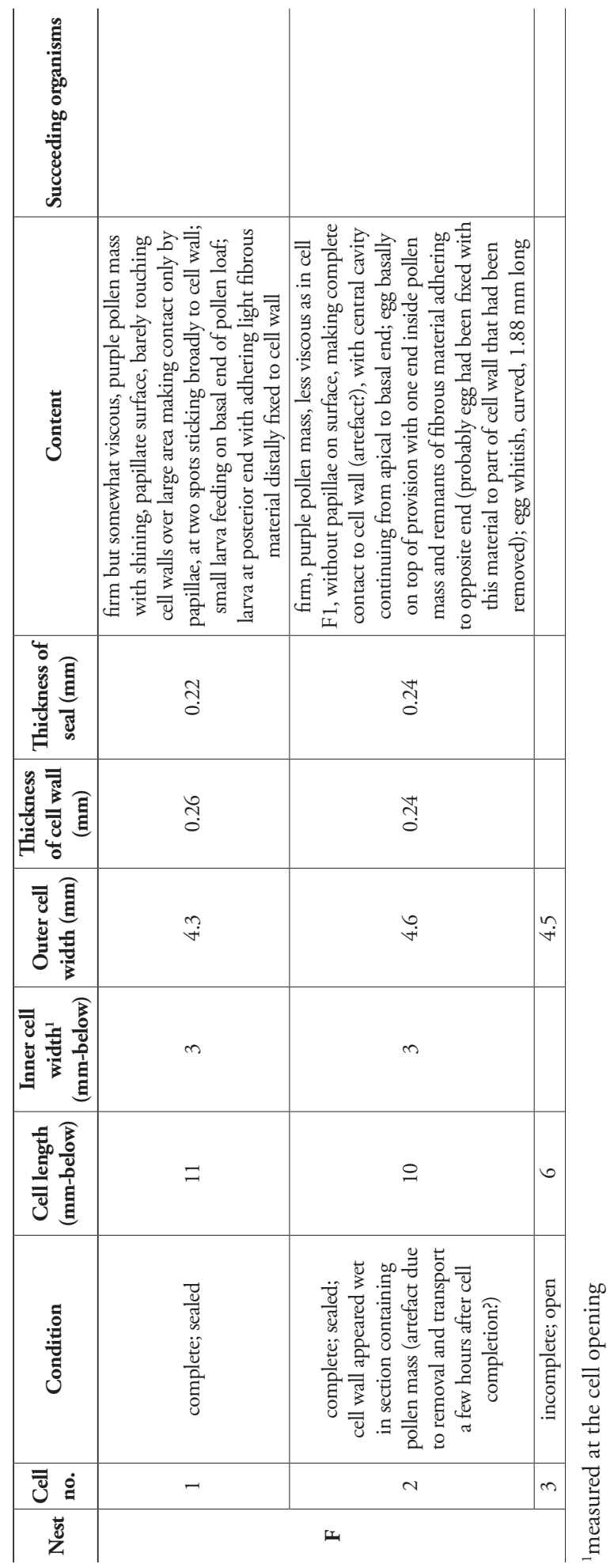


stopped and remained at a certain point head upwards with her body axis orientated in vertical direction (Fig. 27). Then she brought her mouthparts into contact with the substrate and moved slowly downwards (Fig. 28). After contact with the mouthparts the surface had a wet appearance with only very few or completely without adhering soil particles, indicating the application of a fluid. The process took approximately 30-40 s until the female flew off. She returned after 3 to $4 \mathrm{~min}$, with a soil pellet held between her mandibles and labial palpi and alighted on the stem shortly below the nest (Fig. 35). She moved upwards to the point where she had started to apply liquid during the previous visit and began to add the moist soil to the substrate. During the first two or three visits, the female stood on the substrate while building parts of the basal cell wall connecting the cell with the underlying material, i.e. the stem or the wall of the previously build cell $F_{1}$ (Fig. 29). Then she changed her position and held on to the developing basal end of the cell (Fig. 30). Each load of soil was added to the cell in the form of a semi-circular plate, except for material directly applied to the underlying substrate. When building a semicircular plate the female positioned herself with her head and fore legs inside the cell, her metasoma curved around on the outside and her mid and hind legs holding on to the outer surface of the cell wall (Figs 31,32). The mid legs were placed laterally, while the tarsi of the hind legs were positioned medially on the outside in front of the mandibles and the clypeus of the female working as an abutment during the application of the building material from the inside.

The building material was always applied through the moderately opened mandibles supported posterior-laterally by the labial palpi and posterior-medially also by the maxillary palpi (Figs 29, 31). Since the material appeared more shining and runny close to and in front of the mandibles (Fig. 32), it is likely that further liquid was added. The applied material was smoothed and formed with parts of the clypeus and mandibles (Figs 29,30 ) by rubbing movements of the head accompanied by body vibrations. In addition the female infrequently slightly turned her body along the cell margin.

Each period in which building material was added to the cell under construction took between 30-50 s. These material-adding periods regularly alternated with periods during which the female was absent from the nest to collect soil. The median length of soil collection flights was $71 \mathrm{~s}$ (range 53-125 $\mathrm{s} ; \mathrm{n}=6$ ). The complete sequence of soil collection flight and material application took $119 \mathrm{~s}$ in the median (range 90-137 s; $\mathrm{n}=5$ ). Alternating with a cycle of cell construction and soil collection were longer intervals during which the female was away from the nest probably for refilling her crop with liquid. As in the area there was no source of water it seems probable that the female collected nectar. Absence for liquid collection took $23 \mathrm{~min}$ in the median (range 17-29 $\min ; \mathrm{n}=9$ ).

After the building of cell $\mathrm{F}_{2}$ had been completed, the female flew off and was absent from the nest for $28 \mathrm{~min}$. She returned at $16 \mathrm{~h} 58$, alighted on the stem shortly below the nest and entered the new cell head first. Inside the cell she remained active and the tip of her metasoma became repeatedly visible in the cell opening performing vigorous transverse contractions with high frequency (Fig. 37). Occasionally, in addition, she turned slightly around her longitudinal axis. At $17 \mathrm{~h} 16$ she was deep inside the 


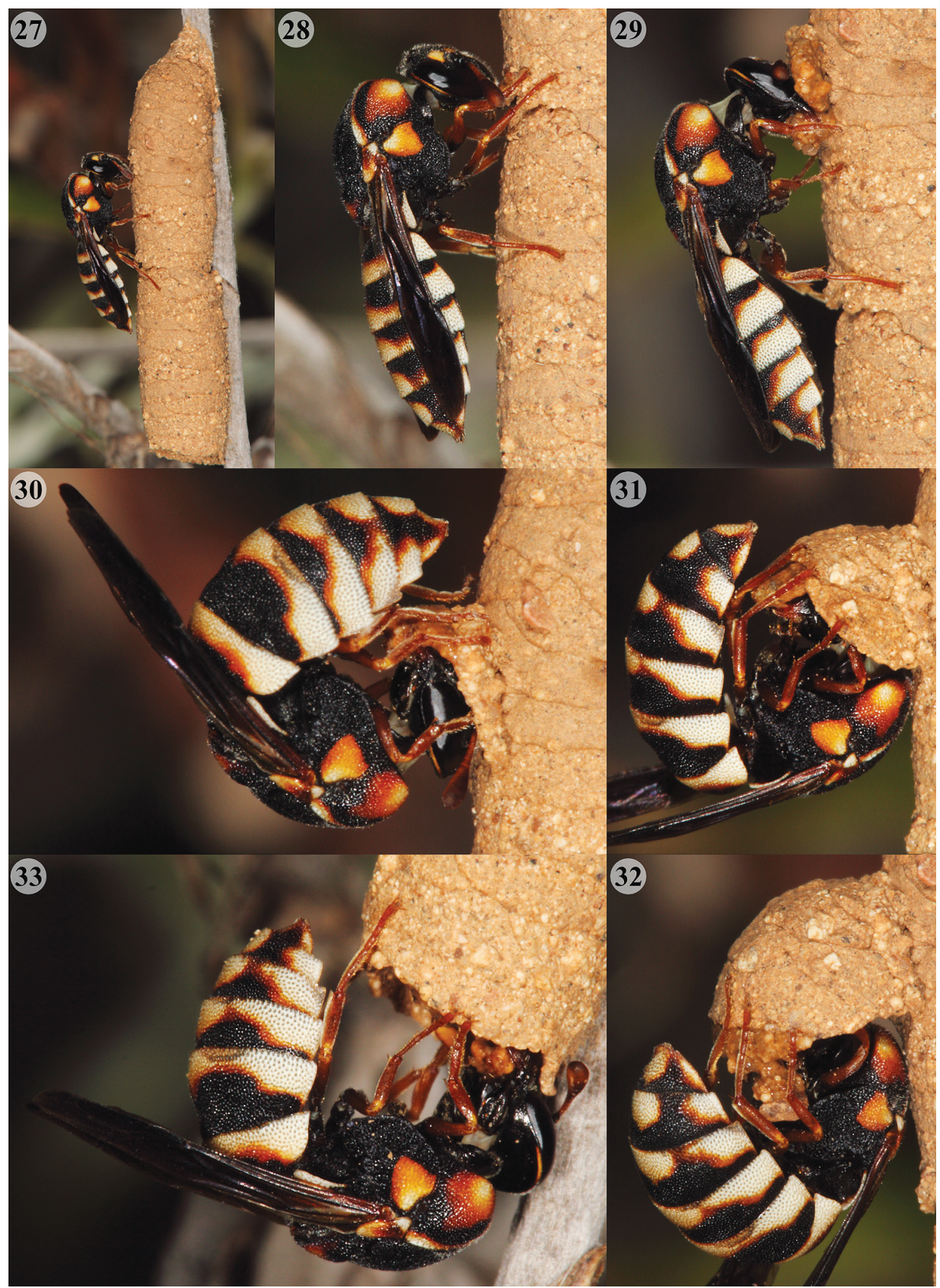

Figures 27-33. Nest building behaviour of Celonites fischeri at nest F: $\mathbf{2 7}$ Following the orientation walk the female has stopped and is touching the substrate with her mouthparts at the place where she will later construct the basal end of the new cell during the subsequent visits. Note that she is not carrying a soil pellet 28 The female has moved slowly downwards keeping her mouthparts into contact with the outer surface of cell $F_{1} 29$ The female is building parts of the basal cell wall of cell $F_{3}$ standing on the surface of cell $F_{1}$ 30-32 The female holds on to the wall of the cell $F_{3}$ adding soil pellets in the form of semi-circular plates. The hind legs are used as abutment while the material is applied with the mouthparts from the inside 33 The female is sealing cell $\mathrm{F}_{2}$. 


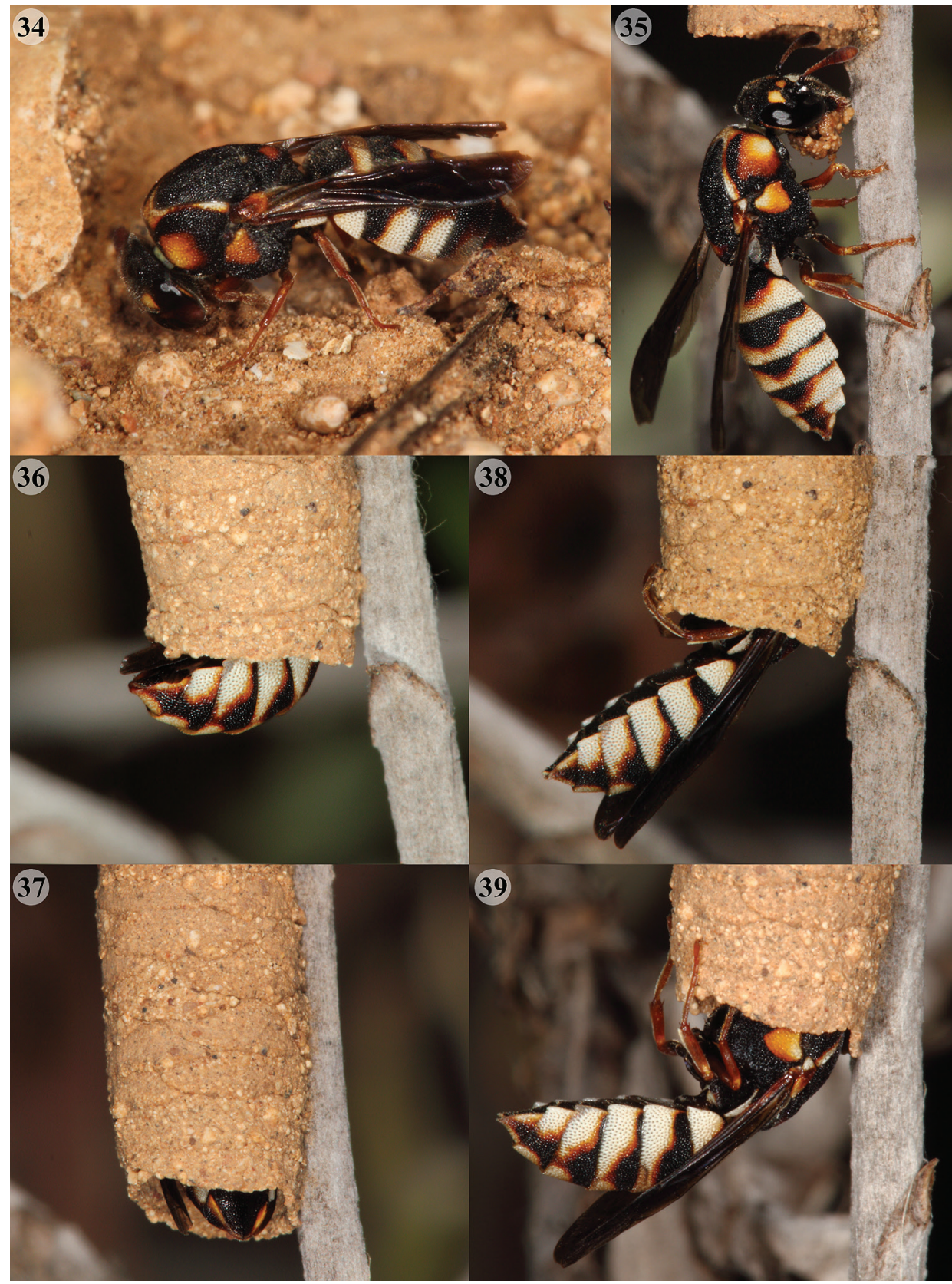

Figures 34-39. Behaviour associated with female brood care in Celonites fischeri: 34 Female taking up soil at a quarry site $\mathbf{3 5}$ After alighting on the stem below nest $\mathrm{F}$ the female is moving upwards to the nest with a soil pellet held between her mouthparts 36 Female resting in cell $F_{1}$ in the evening. Note that her wings are folded underneath her metasoma and that she probably could not move deeper inside the partly provisioned cell 37 Female remaining active inside cell $\mathrm{F}_{2}$. Note that her wings are in their normal dorsal position 38 Female depositing a portion of the provision of cell $F_{1}$ after a pollen collecting trip 39 On a subsequent visit the female has to stay further outside the cell than before during provisioning due to the increased volume of the provision inside the cell. 
cell, with her still contracting metasoma directed towards the cell opening (observed with a mirror). On the following inspection at $17 \mathrm{~h} 29$ the female remained motionless in a curled position in the lower part of the cell with her head close to the entrance. This was the only occasion in which the female was observed with her genital chamber directing towards the basal end of the cell indicating that oviposition had taken place. At $17 \mathrm{~h} 32$ the female appeared in the entrance head first, left the cell, turned around and re-entered the cell head first directly thereafter and finally remained motionless deeply inside the cell with her wings folded in resting position underneath the metasoma directed towards the cell opening.

Throughout the provisioning phase the female regularly alternated between periods in which she was absent from the nest to perform provisioning flights and visits to the nest to deposit a portion of larval provision. A provisioning flight took $37 \mathrm{~min}$ in the median (range 24-73 $\mathrm{min} ; \mathrm{n}=20$ ). On return the female always alighted on the stem shortly below the nest and moved upwards directly into the cell head first. Within the cell the female gradually turned around her longitudinal axis, regularly interrupted by short periods during which she remained in her attained position. The direction of the rotations was either clockwise or counter clockwise and sometimes the female changed the direction within a single visit. At the same time her metasoma performed vigorous transverse contractions with high frequency. Sometimes telescopic contractions in longitudinal direction occurred in addition. On subsequent visits the wasp could move less and less deeply into the cell, since the volume of the provision increased with each deposit. Therefore, whereas at the beginning of the provisioning phase only the tip of her metasoma remained visible in the cell entrance, later on the metasoma and parts of the mesosoma protruded more and more from the cell. At this stage the female held onto the margin of the cell opening or the stem with her hind legs and finally also her mid legs bending her metasoma ventrad at an angle of approximately $60^{\circ}$ against the longitudinal axis (Figs 38, 39). Leaving the nest the female backed out of the cell holding on to the opening and the outer cell wall with her hind and mid legs thus turning her longitudinal axis obliquely downwards. In this position she removed her head and fore legs from the cell entrance, turned her body upwards around the cell margin and walked at least a few steps on the outer surface towards the upper half of the cell. Here the female often remained for a few seconds until she flew away (Fig. 40). Visits to the cell for provisioning took $4 \mathrm{~min}$ in the median (range 2-7 min; $\mathrm{n}=22$ ).

The sealing phase started with the absence of the female from the nest for 7 to 17 min respectively. She returned with a soil pellet, alighted on the stem shortly below the nest and walked upwards. The female positioned herself directly below the cell entrance holding on to the apical margin of the cell with her mid and hind legs (Fig. 33) or to the stem just below it, while her head and fore legs were inside of the cell opening (Fig. 41). She applied the building material with her mouthparts sometimes accompanied by nodding movements of her head turning gradually around the cell opening. Sealing of a brood cell required 3 to 6 visits respectively, each lasting 30-50 s. The visits were regularly interrupted by soil collection flights taking $64 \mathrm{~s}$ in the median (range 26-164 s; $\mathrm{n}=7$ ). 


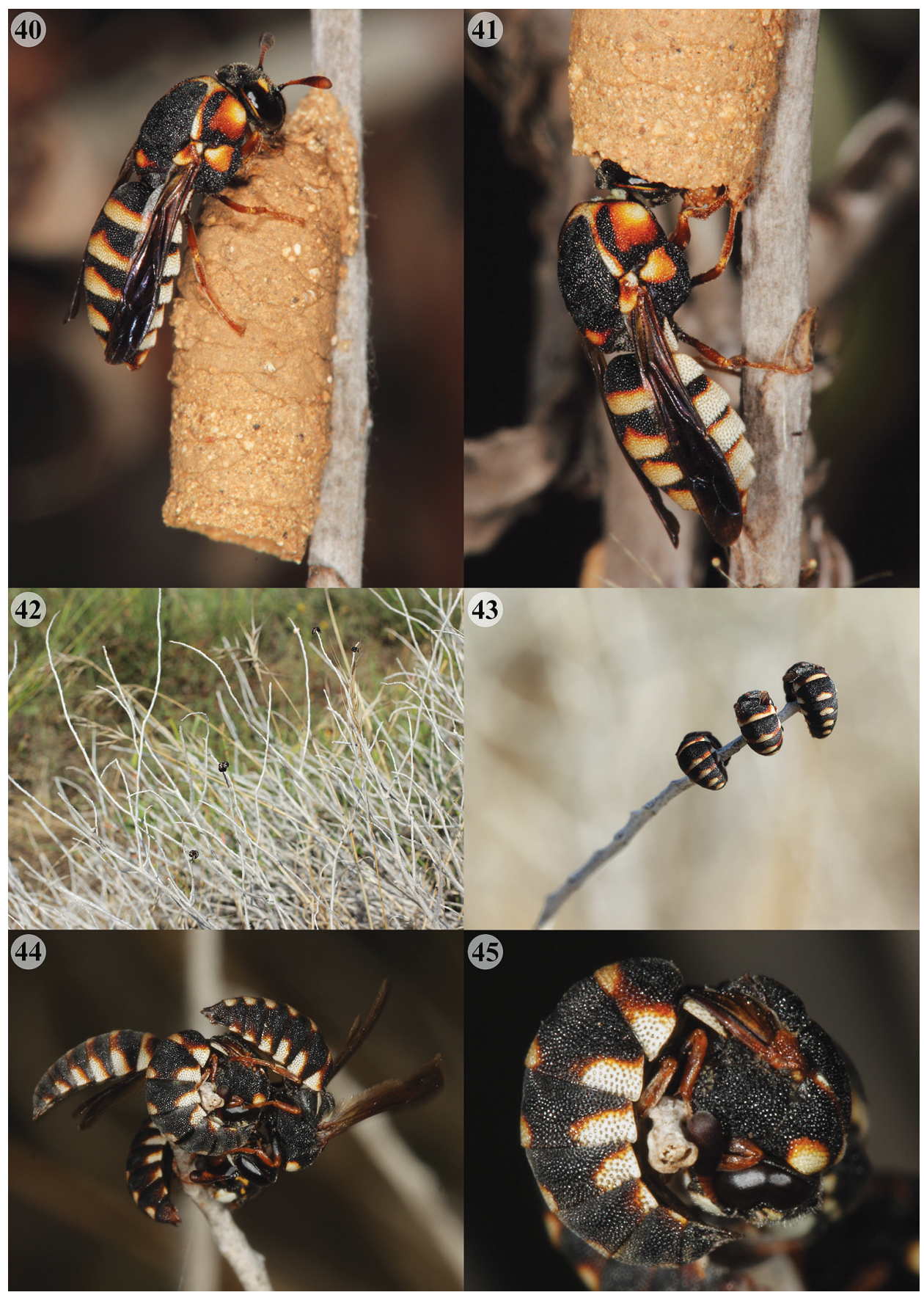

Figures 40-45. 40 Female of Celonites fischeri remaining briefly on top of cell $\mathrm{F}_{1}$ before taking off. $4 \mathrm{I}$ Female of $C$. fischeri sealing cell $\mathrm{F}_{2}$ holding onto the stem below it 42-45 Behaviour of $C$. fischeri males at locality I Kato Paphos $\mathbf{4 2}$ Males aggregated in groups at withered stem ends of a dwarf shrub 43 Group of three males in sleeping position $44 \mathrm{~A}$ late arriving male has alighted on the male at the top of the group and is walking over it $\mathbf{4 5}$ Male in sleeping posture (viewed from the right). 
Altogether the construction of brood cell $\mathrm{F}_{2}$ required seven cycles of cell construction and soil collection in connection with seven preceding liquid collection flights taking $247 \mathrm{~min}$ in total (Fig. 48). Oviposition took place within less than 15 minutes. The provisioning phase included 14 provisioning flights and visits to the cell lasting $707 \mathrm{~min}$ in total. Finally the cell was sealed within $27 \mathrm{~min}$. The cell building rate can be roughly estimated as one completed cell per two days. Cell building was initiated around midday and was finished by the end of the flight period of the same day and was followed by oviposition in the late afternoon. Provisioning took the second day and the morning of the third. Finally the cell was sealed around midday of the third day. Shortly thereafter the female started again with the building phase of another brood cell.

In all visits to the nest the female followed a characteristic pattern of orientation. On return she always alighted on the stem shortly below the nest and walked upwards to the cell (Fig. 35). On departure she walked upwards on the outer surface of the cell where she often remained for a moment before she flew off (Fig. 40). During the night the female always remained motionless in the cell in a characteristic posture with her wings folded underneath her metasoma (Fig. 36).

Soil collection: Two females of Celonites fischeri were observed to collect soil at a quarry site, which was a bare area with fine clayey soil measuring approximately $30 \times 30$ $\mathrm{cm}$ (Fig. 2). During consecutive visits each female always alighted on the same spot of the quarry site with identical orientation of her body axis. Within a soil collecting cycle a female arrived every 2-3 minutes at the quarry site. Soil uptake took $20.7 \mathrm{~s}$ in the median (range 20.6-21.6 $s ; \mathrm{n}=3$ ). For soil collection a female stood on the ground with her mid and hind legs moving her head vigorously in a high frequency in dorsoanterior and ventro-posterior direction while scraping up a load of soil with opened mandibles which were moving inwards and outwards (Fig. 34). The process was supported by irregular movements of the forelegs with lower frequency. The removed soil had a wet appearance indicating that liquid was used during soil uptake. The moist soil particles accumulated behind the mouthparts forming a pellet that was held with the aid of the labial palpi. Finally, held securely in this position by the mandibles and labial palpi the soil pellet was carried in flight to the nest.

\section{Male sleeping aggregations}

One male sleeping aggregation was recorded at locality I and two separate aggregations at locality II (Fig. 46). The males aggregated for the night in small areas of less than 0.1 $\mathrm{m}^{2}$ where they slept together in groups curled up around fine, withered stem ends of herbaceous plants or dwarf shrubs (Figs 42, 43). The males used the same sites over a period of at least 10 to 11 days, but there was some variation regarding the particular stems used. Moreover, the total number of males and the number and size of male groups within an aggregation varied noticeably over the observation period (Fig. 49). The median number of males per aggregation and night was 7 (range $0-13 ; n=27$ ) 


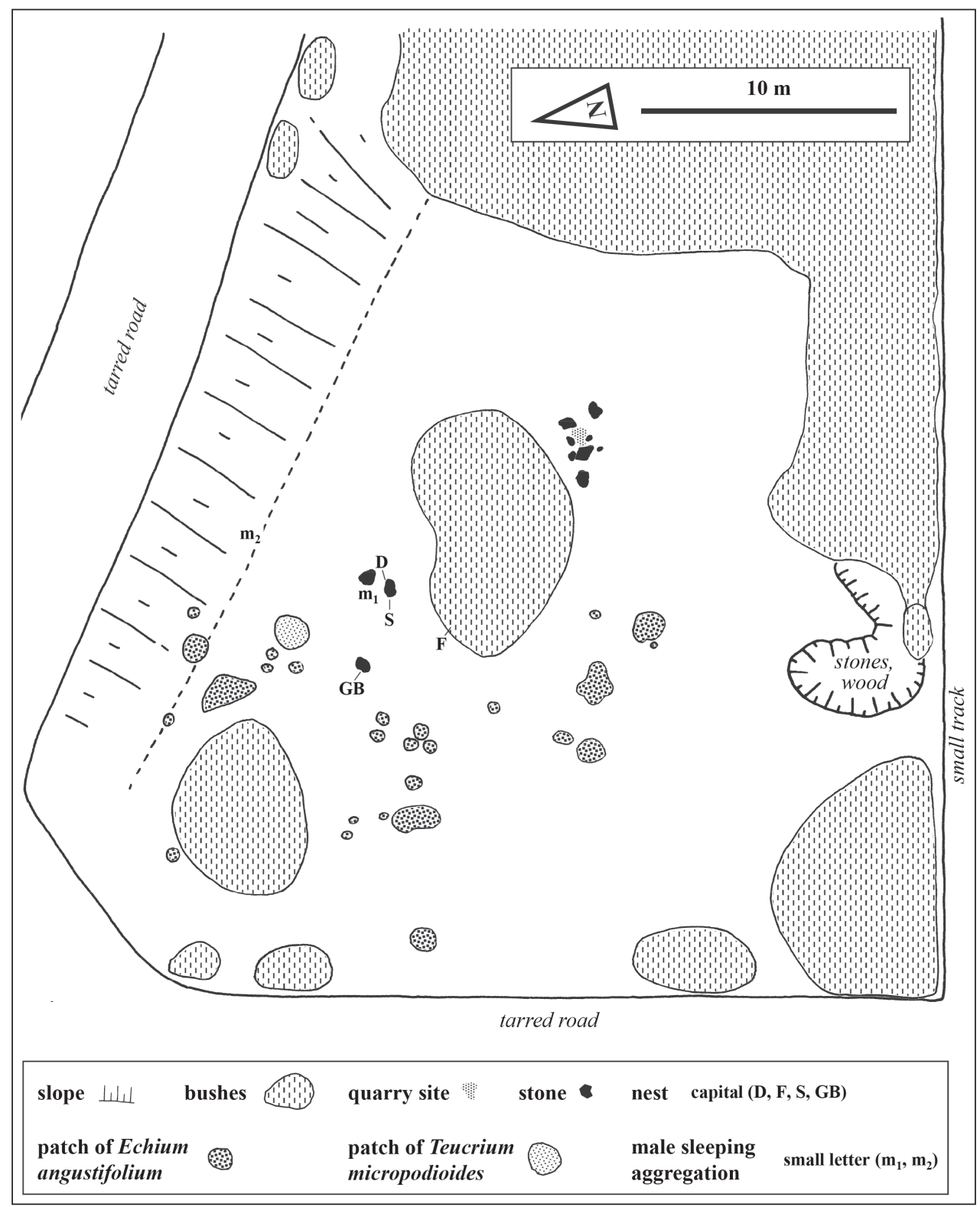

Figure 46. Schematic map of the main study area of Celonites fischeri at locality II $0.5 \mathrm{~km}$ north of Agios Georgios, Cyprus.

divided into 3 groups (range $0-6 ; \mathrm{n}=27$ ). Stem ends used by male groups were about $5-30 \mathrm{~cm}$ away from each other and about $20-40 \mathrm{~cm}$ above the ground. Group size varied from 1-5 males (median number $=2 ; \mathrm{n}=83$ ) (Fig. 50). The distance between neighbouring males within a group varied between $0 \mathrm{~mm}$ (i.e., in physical contact with 


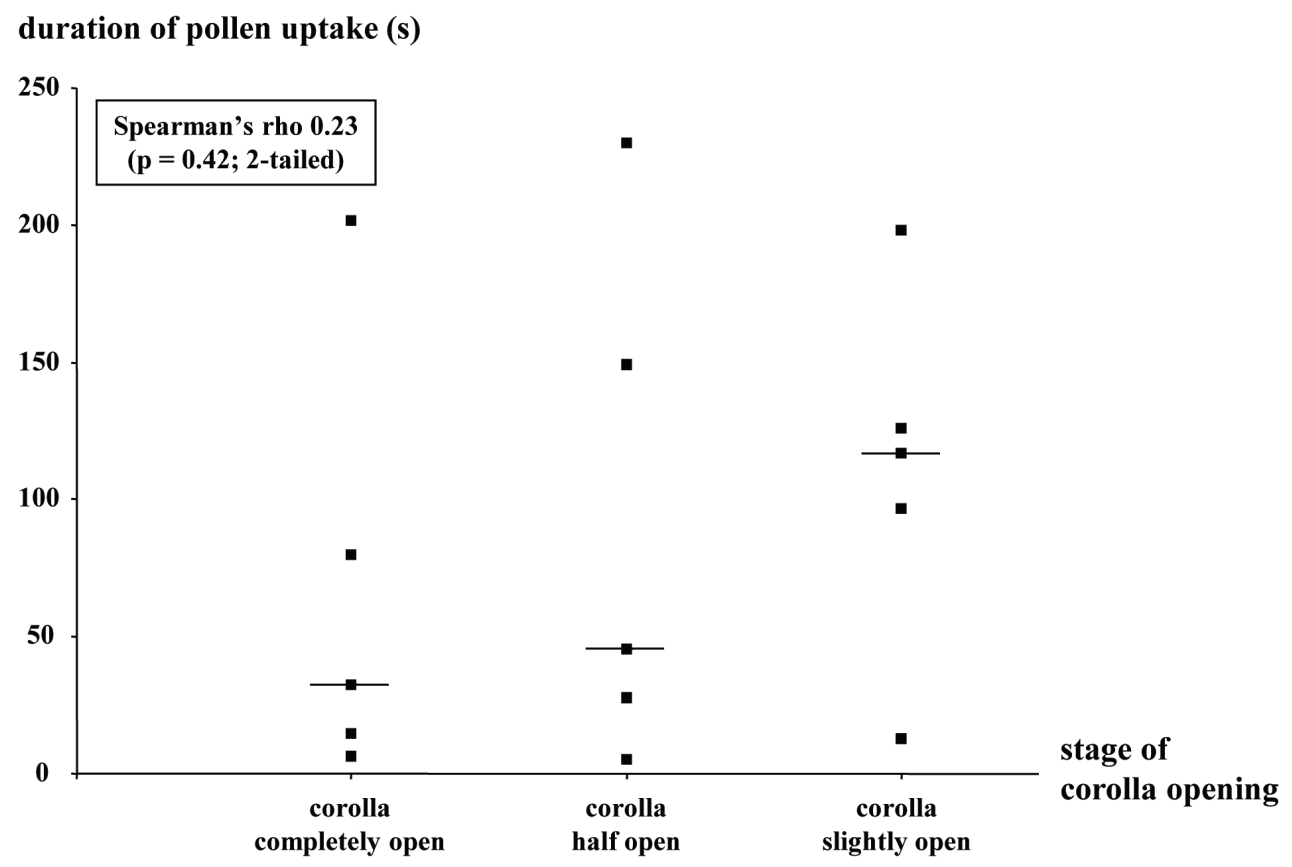

Figure 47. Correlation between the duration of pollen uptake by flower visiting females of Celonites fischeri and the stage of corolla opening of the visited flower of Echium angustifolium (median marked with line).

each other) and $7 \mathrm{~mm}$, in one instance it was $50 \mathrm{~mm}$. All males adopted the same typical posture; the bodies were curled clockwise or anticlockwise around the stem so that the tip of the metasoma covered the ventral part of the head. Antennae and legs were pulled up under the mesosoma, and the wings were folded underneath the metasoma (Fig. 45).

Formation of the sleeping aggregations started in the afternoon between $15 \mathrm{~h} 00$ and 16h00, when males began to alight and perch frequently on fine, withered stem ends in the area of the aggregation. Some of the males also started to adopt the sleeping posture and curled their bodies part way around the end of a stem. However, group formation led to a lot of interactions and disturbance, since newly arriving males repeatedly alighted on males that had already occupied a sleeping position (Fig. 44). Later appearing males often tried to reach a position at the top of the group or between two other males. This sometimes resulted in a few or all of the males flying up and immediately returning thereafter, even though not always to the same stem. The last male interactions were recorded between $17 \mathrm{~h} 00$ and $18 \mathrm{~h} 00$. After that all males remained motionless at their final position in sleeping posture until the end of the observation period in the evening. In the morning males were observed to leave the sleeping aggregation before $9 \mathrm{~h} 00$ at locality I and between $9 \mathrm{~h} 30$ and $10 \mathrm{~h} 00$ at locality II respectively. 


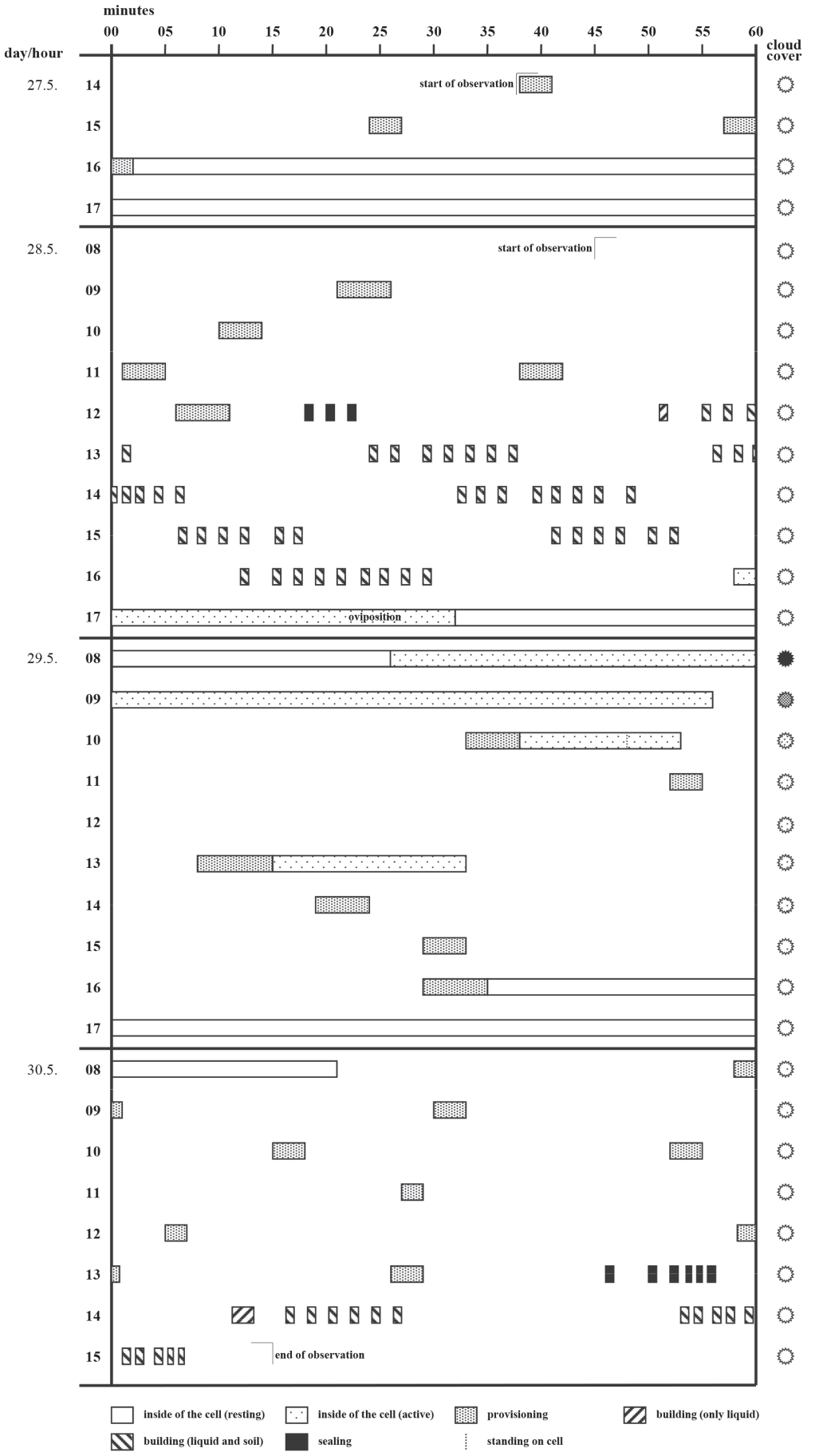

Figure 48. Ethogram of female brood care behaviour of Celonites fischeri based on continuous focal observation of nest F from 27 May until 30 May 2013 (interrupted only during the resting period of the female during the night; total observation time $27.5 \mathrm{~h}$ ). 

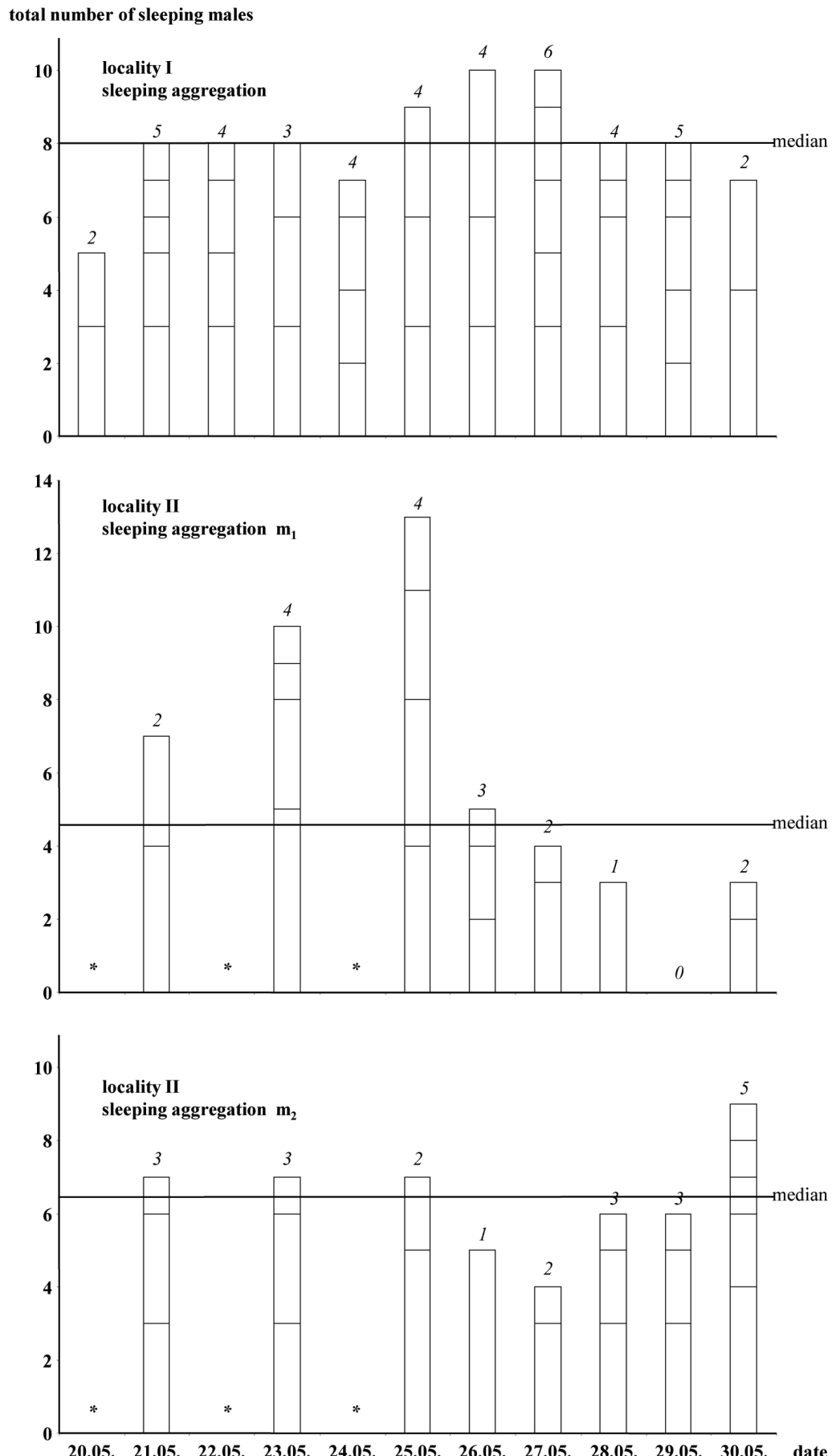

- $=$ partition between different male groups $\quad x=$ number of male groups $\quad *=$ data lacking

Figure 49. Total number of males, the number of male groups and size of male groups within three male sleeping aggregations of Celonites fischeri from 20 to 30 May 2013 based on counts made in the evenings. 


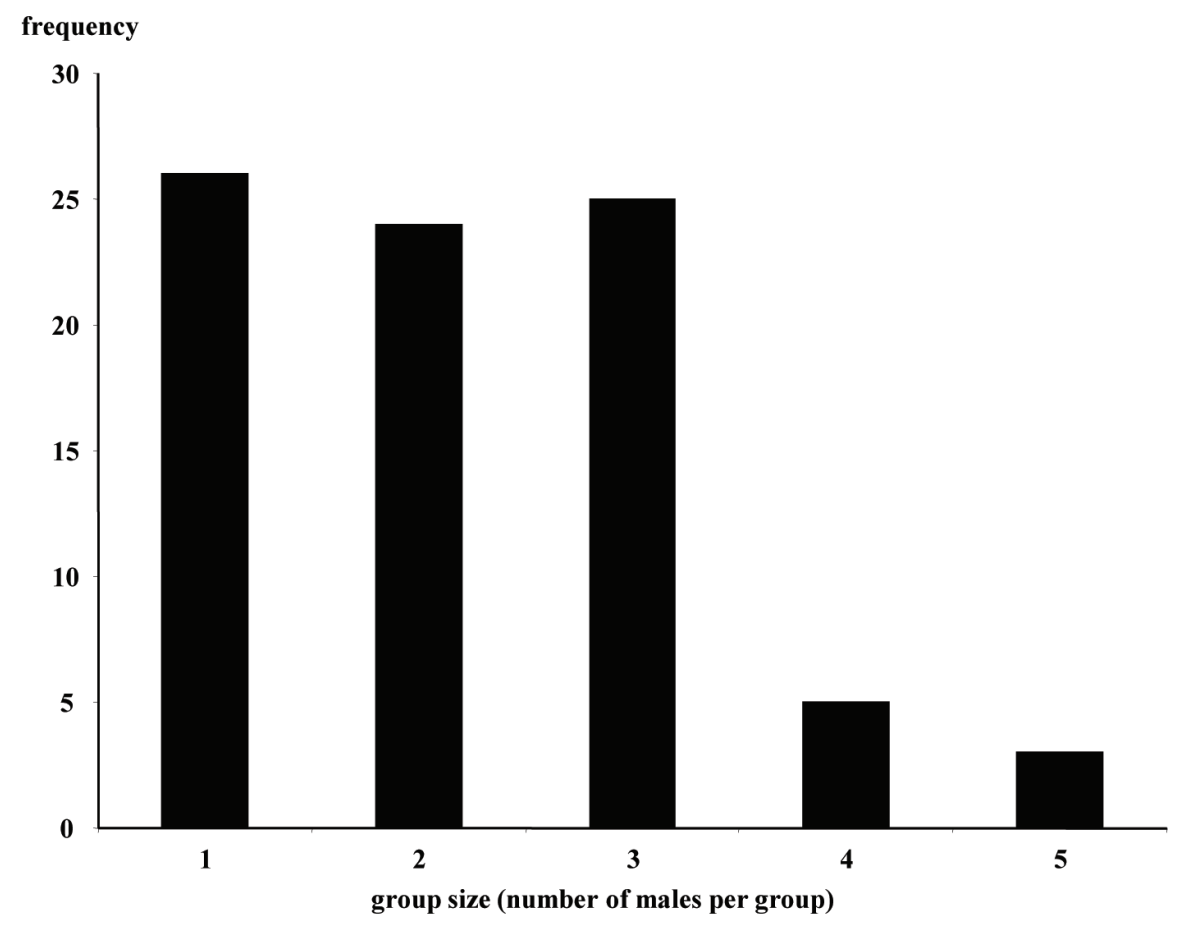

Figure 50. Range and frequency of group size in male sleeping aggregations of Celonites fischeri based on 83 registered male groups from three aggregations at two different localities in Cyprus from 20 to 30 May 2013.

\section{Associated organisms}

A single brood cell had been parasitized by an unknown holometabolic insect (Fig. 24, Table 2).

After emergence of the imagines the old cells of Celonites fischeri were regularly inhabited by little jumping spiders (Salticidae). Old cells were also used by solitary bees as pre-existing cavities for nesting (Fig. 25, Table 2).

\section{Discussion}

\section{Flower association}

At all Cyprian localities, males and females of Celonites fischeri were observed to visit only flowers of Echium angustifolium for nectar and pollen uptake. Likewise, the content of the female alimentary tracts and the two brood cell provisions investigated exclusively consisted of Echium pollen. This is in accordance with the only flower visiting record published for $C$. fischeri, i.e. a photo of a pollen collecting female at an Echium flower taken by Weinstein (2008) in Israel. Therefore, C. fischeri is most prob- 
ably narrowly oligolectic, using flowers of Echium as the sole pollen source. Oligolecty or narrow polylecty are the rule for many species of the Masarinae and are common in Celonites (Gess 1996; Gess and Gess 2010). An association with flowers of Boraginaceae has also been established for Celonites heliotropii Gess, 2007 in the Afrotropical region (Gess 2007) and may also exist in eight additional Celonites species from the Palaearctic, which were observed to visit plants of this family (summarized in Gess 1996). Interestingly, C. afer, which is the closest relative of $C$. fischeri, has also been recorded from four North African species of Echium (Bequaert 1940), suggesting that both species of the $C$. fischeri-complex are associated with this plant genus. This flower specialisation might explain the absence of knobbed setae on frons and clypeus of $C$. fischeri and C. afer, since Echium flowers are sternotribic. In contrast, the knobbed setae of the species of the C. abbreviatus-complex serve to harvest pollen from nototribic flowers of the Lamiaceae (Schremmer 1959; Müller 1996). Females of C. abbreviatus collect pollen from Lamiaceae species by rubbing the knobbed setae over the anthers so that pollen grains accumulate on the frons. Afterwards, the pollen is transferred from the head to the mouthparts by brushing movements of the fore legs (Schremmer 1959; Bellmann 1995; Müller 1996; Mauss 2006). In contrast, pollen gathering females of C. fischeri ingest pollen directly from the anthers of the Echium flowers with the aid of the fore tarsi. This corresponds closely to the pollen collecting behaviour of most other Masarinae, which either ingest pollen directly from the anthers or use their fore legs to work the anthers and draw the pollen towards their mouthparts (Gess and Gess 1989; 1990; cf Gess 2004; cf Neff and Simpson 1985; cf Torchio 1970). Interestingly, the females of $C$. fischeri perform a remarkable pollen collecting strategy, which has never been described in pollen wasps before in that they gather pollen from Echium flowers that have just started to open by forcing their heads into the only slightly opened corolla. The regularly observed "inspection flights" of the females (see Results) may serve to increase the probability of locating flowers in an early stage of flowering, which are expected to offer higher amounts of pollen in comparison with older flowers, in which the pollen has already been depleted by other flower visitors. At least some of these competitors are not able to collect pollen from the flowers before the anthers are accessible for regular flower visits. This pertains for instance to oligolectic megachilid bees of the genus Osmia (subgenus Hoplitis), which take up pollen from Echium flowers with a scopa on the underside of the metasoma. Despite its distinct pollen collecting strategy, Celonites fischeri seems to collect pollen less efficiently than C. abbreviatus as indicated by significantly longer provisioning trips performed by the female from nest F in comparison with the C. abbreviatus female studied by Bellmann (1984) (Table 3; Mann-Whitney Test: $\mathrm{p}(2$-tailed $)<0.001)$. The difference could be related to the specialized pollen collecting apparatus of $C$. abbreviatus. However, the hypothesis that indirect pollen uptake with knobbed setae is more efficient than direct pollen uptake from the anthers should be tested in more detail at different localities and with a higher sample size.

During nectar uptake the body of Celonites fischeri is inverted by $180^{\circ}$ so that the dorsal side of the wasp projects towards the reproductive organs of the Echium flower 


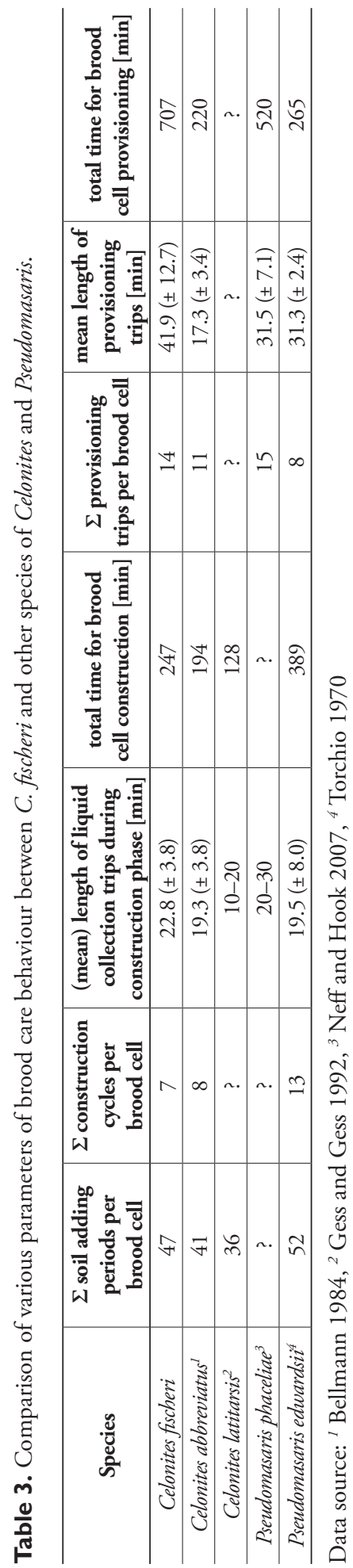


without coming into contact with the stigma. Therefore nectar visits of $C$. fischeri to Echium flowers have to be regarded as illegitimate visits and $C$. fischeri is probably not an efficient pollinator of the plant.

\section{Mating}

Males of Celonites fischeri regularly seek for mates patrolling Echium patches. This is in congruence with the behaviour of C. abbreviatus and several Afrotropical species of Celonites that also search for females at floral resources (Mauss 2006; Gess and Gess 2010). However, the single copulation of $C$. fischeri observed in the area of a sleeping aggregation indicates that further mating strategies exist, independent of flowers.

The general behaviour during copulation is similar in Celonites fischeri and C. abbreviatus. In both species the initiation starts with a patrolling male pouncing on a female and the position of the male on the female during the insertion phase is quite similar (cf Mauss 2006). Insertion length is similar among the species and takes only about $10 \mathrm{~s}$ (cf Mauss 2006). However, the initial anterior position of the male on the female and the short protrusion of the distal end of the proboscis in C. fischeri were not described for $C$. abbreviatus (Mauss 2006). This could be due to the less complete photographic documentation of copulation behaviour in C. abbreviatus that did not allow more detailed analysis of "grappling" (Mauss 2006) between both partners in this phase. For other species of Celonites actual copulation has not been observed (Gess and Gess 2010). A comparable movement of the male backwards on the female's back has also been observed in the copulation of Pseudomasaris where it is combined with a series of strokes with the elongated male antennae on the head of the female (Longair 1987).

\section{Female brood care}

The recorded nests of Celonites fischeri were aerial and completely exposed although somewhat hidden by vegetation. This is quite similar to nest sites of $C$. abbreviatus with the exception that in $C$. abbreviatus nests are located exceptionally in pre-existing cavities on the underside of stones in addition (Bellmann 1984). Nests of Afrotropical species of Celonites are mainly in protected situations (Gess and Gess 2010) apart from a putative nest of $C$. promontorii Brauns, 1905 that was completely aerial, exposed on a stem of a dwarf shrub (Gess and Gess 1989). Nests of $C$. fischeri were built on stones or plants. The same variability regarding the nest substrate has been reported for $C$. abbreviatus (on a dry stem Lichtenstein 1869, on stones Ferton 1901, 1910; Bellmann, 1984, 1995) and C. andrei Brauns, 1905 (Brauns 1913) and is also present in Pseudomasaris phaceliae Rohwer, 1912 (Neff and Hook 2007) and P. edwardsii (Cresson, 1872) (Torchio 1970). The single known nest of C. mayeti described by Lichtenstein (1875) was attached to a stone. The nests of $C$. fischeri in Cyprus were not orientated towards the south, probably to avoid strong irradiation by the sun that may cause over- 
heating in the hot Mediterranean summer. In contrast the majority of the nests of $C$. abbreviatus from Central Europe are exposed to the sun (Bellmann 1995).

The covering of a nest of Celonites fischeri with a thin layer of earth is similar to the observed nest covering in C. abbreviatus (Bellmann 1984). However, in two out of three old nests of $C$. fischeri a nest covering was lacking. Variation in the presence and degree of development of a nest covering has also been reported for C. abbreviatus (Bellmann 1995) as well as for Pseudomasaris edwardsii (Torchio 1970) and P. phaceliae (Neff and Hook 2007). It is unknown whether this is caused by external disruption of nest construction behaviour or by behavioural variance.

In the recorded nests of Celonites fischeri the average number of cells was $3.0( \pm$ $2.7 ; \mathrm{n}=4)$. This is within the range of the number of cells in nests of $C$. abbreviatus recorded by Bellmann (1984), although his average number of cells per nest was slightly higher, $4.1( \pm 2.7 ; \mathrm{n}=11)$. In nests of $C$. fischeri the brood cells are attached to each other both longitudinally and linearly. This variable arrangement of the brood cells is also present in C. abbreviatus (cf Lichtenstein 1869; Ferton 1901; Bellmann 1984) and C. michaelseni Schulthess, 1923 (Gess et al. 1997) but it seems to be absent in C. andrei (Brauns 1913) and species of Pseudomasaris (Neff and Hook 2007; Torchio 1970) in which the cells are only longitudinally attached to each other. The brood cells of the single nest of $C$. mayeti (Lichtenstein 1875) and a single putative nest of $C$. promontorii (illustrated in Gess 1996) were also connected longitudinally. The linear arrangement of cells in nests of Celonites may be associated with the characteristic frontal or lateral situation of the emergence hole in the wall of the brood cells of $C$. fischeri and also $C$. abbreviatus (Bellmann 1995). Emerging through the cell wall instead of the original cell opening is possibly a precondition for a linear cell arrangement. Otherwise the emerging wasp would have to break at least through one adjacent cell. In contrast the adults of Pseudomasaris phaceliae remove the old seal and emerge through the original apical cell opening (Neff and Hook 2007).

The brood cells of Celonites fischeri correspond well to the cells of all other Celonites species in the distinct "fish scale" pattern on the outer surface, the smooth inner surface of the constructed earthen cell and the construction of the seal just inside the cell opening (Bellmann 1984; Gess and Gess 2010). These characters are also present in the aerial brood cells of Pseudomasaris (Neff and Hook 2007; Torchio 1970). However, the cells of $C$. fischeri are almost parallel sided, as in C. abbreviatus (Bellmann 1984), while the cells of Afrotropical species of Celonites are more ovoid (Gess and Gess 1989, 1992, 2010; Gess et al. 1997).

The cocoon of Celonites fischeri is whitish to yellow-whitish and thin becoming more sparsely or even completely absent towards the basal end of the cell. This is in congruence with the cocoon of $C$. abbreviatus that has been described as white and very thin (Bellmann 1984). The meconium of $C$. fischeri looks similar to the fecal mass of Pseudomasaris edwardsii figured by Torchio (1970: Fig. 21) consisting of compressed fecal pellets. Comparable smooth, flattened semicircular pellets have been described for P. phaceliae (Neff and Hook 2007). This is the first documentation of the meconium of a Celonites species. 
The behavioural sequence and specific manners of the Celonites fischeri female during nest construction generally resembles the nest building behaviour of $C$. abbreviatus (Table 3, cf Bellmann 1984, 1995).

In Celonites fischeri the cell building phase was always initiated by the female walking randomly over the brood cells and finally adding some fluid without or nearly without soil particles to the substrate at the future site of the new cell. This preparation of the new starting point seems to serve as some kind of marking, since afterwards the female always moved directly towards the new construction site. It is unclear whether a similar orientation and initiation sequence is present in C. abbreviatus, since Bellmann (1984) started his focal observation only when the female was already building the second segment of the brood cell. A comparable initiation behaviour at the beginning of the cell building phase has been described in Pseudomasaris edwardsii (Torchio 1970).

During cell building the female of Celonites fischeri always placed the tarsi of her hind legs on the outside of the cell immediately in front of her head working as an abutment while she was applying material with her mouthparts from the inside. This characteristic posture is also adopted by $C$. abbreviatus during cell building (Bellmann 1984). However, in 1995 Bellmann stated that the tip of the metasoma is used as a "trowel" during the application of soil, but this is in contradiction to all of his published figures (Bellmann 1984: Fig. 2, 1995: p. 150) and to his particular emphasis from 1984 that the metasoma of the female did not come into contact with the cell wall. In contrast, in Pseudomasaris use of the posterior metasomal sterna in nest building has been proven in P. edwardsii (Torchio 1970) and P. phaceliae (Neff and Hook 2007) and soil application to the cell wall occurs without direct involvement of the hindlegs that are situated more laterally.

The soil collection behaviour of Celonites fischeri is similar to soil uptake of C. latitarsis Gess, 1992 and C. wahlenbergiae Gess, 1989 (Gess and Gess 1992). These species use also defined quarry sites on small bare areas, here stabilized molerat "hillocks", where the females vibrate up and down vigorously apparently loosening sand with their mandibles (Gess and Gess 1992). Celonites latitarsis visits to the quarry site take an average of 29 s (Gess and Gess 1992) which is comparable with 21 s taken by C. fischeri.

The temporal pattern of cell building behaviour is rather similar in Celonites fischeri and C. abbreviatus (cf Bellmann 1984). In both species cell construction is initiated in the middle of the day, is finished in the late afternoon and is immediately followed by egg-laying. Afterwards the female spends the night inside the new cell and starts to provision it in the morning of the following day. However, the length of the provisioning phase seems to differ lasting one and a half day in $C$. fischeri, but only a half day in $C$. abbreviatus. Despite this difference provisioning is finished in both species at the end of the morning and is directly followed by sealing the cell. The focally observed female of $C$. fischeri completed about half a brood cell within 24 hours whereas a female of $C$. abbreviatus completed a whole cell within 24 hours (Bellmann 1984). The divergent cell building rate is mainly the result of a shorter provisioning period in C. abbreviatus (Table 3 ) indicating once more that $C$. abbreviatus may collect pollen more efficiently than $C$. fischeri (see above). 
The reproductive success of Celonites fischeri at the time and place of the present study can be estimated from the content of the old brood cells; from nine old brood cells six showed signs of successful development of Celonites offspring while three failed (Table 2). Therefore two-thirds of the completed brood cells of a female develop successfully. Success rate can be expected to vary from year to year and place to place, depending upon e.g. weather conditions, availability of provision and occurrence of nest parasites. The total number of cells that a female may construct has yet to be established.

\section{Male sleeping aggregations}

The formation of male sleeping aggregations in Celonites fischeri is in congruence with the behaviour of $C$. abbreviatus the only member of the Masarinae in which male sleeping aggregations have been recorded previously (Amiet and Mauss 2003). In both species the characteristic sleeping posture of the males is identical (cf Bischoff 1927; cf Amiet and Mauss 2003) and the males start to aggregate early in the afternoon. As in C. abbreviatus, the males of $C$. fischeri use the same site over several consecutive nights. In $C$. fischeri it has been observed for the first time that number and size of the male groups vary partly between successive nights, indicating some variance in the composition of the male groups. During formation of the aggregation in the afternoon there are several interactions between the males that often try to reach a position at the top of the group. According to Freemann and Johnston (1978) in male sleeping aggregations of various Aculeata roosting in a more apical position is frequently preferred, since it may offer better protection against walking predators that have to approach from the basal or central regions of the plant.

\section{Acknowledgements}

We are especially grateful to Sarah Gess for valuable comments on the manuscript and improvement of our English and to Sarah Gess and Christophe Praz who reviewed the paper carefully. Annette Rosenbauer kindly identified the collected plants. Peter Boye provided literature about Cyprus and Gabriele Hellenschmidt and Katja Bauer translated an article from French.

\section{References}

Amiet F, Mauss V (2003) First report of male sleeping aggregations in the pollen wasp Celonites abbreviatus (Villers, 1789) (Hymenoptera: Vespidae: Masarinae). Journal of Hymenoptera Research 12: 355-357.

Baier F, Sparrow DJ, Wiedl H-J (2009) The Amphibians and Reptiles of Cyprus. Frankfurter Beiträge zur Naturkunde 45: 1-363. 
Bellmann H (1984) Beobachtungen zum Brutverhalten von Celonites abbreviatus Villers (Hymenoptera, Masaridae). Zoologischer Anzeiger 212: 321-328.

Bellmann H (1995) Bienen, Wespen, Ameisen - Hautflügler Mitteleuropas. Kosmos Naturführer, Franckh-Kosmos Verlags-GmbH, Stuttgart, 336 pp.

Bequaert J (1940) Notes on the distribution of Pseudomasaris and the food plants of Masaridinae and Gayellinae (Hymenoptera Vespidae). Bulletin of the Brooklyn entomological Society 35: 37-45.

Bingham CT (1898) The aculeate Hymenoptera procured at Aden by Col. Yerbury RA, Capt. Nurse ISC. Journal of the Bombay Natural History Society 12: 101-114.

Bischoff H (1927) Biologie der Hymenopteren. Springer, Berlin, 598 pp. doi: 10.1007/9783-642-50845-5

Blüthgen P (1961) Die Faltenwespen Mitteleuropas (Hymenoptera, Diploptera). Abhandlunger der Deutschen Akademie der Wissenschaften zu Berlin Klasse für Chemie, Geologie und Biologie 2: 1-249.

Brauns H (1913) Dritter Beitrag zur Kenntnis der Masariden (Hym.) von Südafrika. Entomologische Mitteilungen 2: 193-209.

Carpenter JM (2001) Checklist of species of the subfamily Masarinae (Hymenoptera: Vespidae). American Museum Novitates 3325: 1-40. doi: 10.1206/0003-0082(2001)325<0001:COSOTS $>2.0 . \mathrm{CO} ; 2$

Ferton C (1901) Notes détachées sur l'instinct des Hyménoptères mellifères et ravisseurs avec la description de quelques espèces. Annales de la Societe Entomologique de France 70: 83-148.

Ferton C (1910) Notes détachées sur l'instinct des Hyménoptères mellifères et ravisseurs. Ge Série. Annales de la Société entomologique de France 79: 145-178.

Flint PR, Stewart PF (1992) The birds of Cyprus an annotated check-list. B.O.U. Check-list No. 6: 1-234.

Freeman BE, Johnston B (1978) Gregarious roosting in the sphecid wasp Sceliphron assimile. Annals of the Entomological Society of America 71: 435-441.

Gess FW (2004) A revision of the Afrotropical species of the wasp genus Jugurtia de Saussure, 1854 (Hymenoptera: Vespidae: Masarinae). Journal of the Kansas Entomological Society 77: 669-720. doi: 10.2317/E-27.1

Gess FW (2007) Four new species of the wasp genus Celonites Latreille, 1802 (Hymenoptera: Vespidae: Masarinae) from south-western Africa, designation of neotype for C. michaelseni von Schulthess, 1923, species representation in Namibia, and key to species occurring in Namibia. Journal of Hymenoptera Research 16: 11-29.

Gess FW, Gess SK (1992) Ethology of three Southern African ground nesting Masarinae, two Celonites species and a silk-spinning Quartinia species, with a discussion of nesting by the subfamily as a whole (Hymenoptera: Vespidae). Journal of Hymenoptera Research 1: 145-155. Gess SK, Gess FW, Gess RW (1997) Update on the flower associations of southern African Masarinae with notes on the nesting of Masarina strucki Gess and Celonites gariepensis Gess (Hymenoptera: Vespidae: Masarinae). Journal of Hymenoptera Research 6: 75-91.

Gess SK (1996) The pollen wasps - Ecology and natural history of the Masarinae. Harvard University Press, Cambridge, Massachusetts, 340 pp. doi: 10.4159/harvard.9780674281684 
Gess SK, Gess FW (1989) Flower visiting by masarid wasps in southern Africa (Hymenoptera:

Vespoidea: Masaridae). Annals of the Cape Provincial Museums Natural History 18: 95-134.

Gess SK, Gess FW (1990) Masarid wasps as potential pollinators. African Wildlife 44: 354-358.

Gess SK, Gess FW (2010) Pollen wasps and flowers in southern Africa. SANBI Biodiversity

Series 18: 1-147.

Gusenleitner J (1973) Über Masaridae aus dem nahen Osten (Vespoidea, Hymenoptera). Bolletino della Museo Civico di Storia Naturale di Venezia 24: 55-69.

Gusenleitner J (2002) Neue oder bemerkenswerte Vespoidea aus dem Nahen Osten (Hymenoptera: Eumenidae, Masaridae). Linzer biologische Beiträge 34: 335-343.

Gusenleitner J (2007) Eine neue Celonites-Art aus Sibirien (Hymenoptera: Vespidae, Masarinae). Linzer Biologische Beiträge 39: 133-135.

Gusenleitner J (2012) Neue Masarinae aus der paläarktischen Region (Hymenoptera: Vespidae: Masarinae). Linzer Biologische Beiträge 44: 319-326.

Lichtenstein J (1869) no title. Annales de la Société Entomologique de France (4) 9, Bulletin entomologique, XXIX.

Lichtenstein J (1875) no title. Annales de la Société Entomologique de France (5) 5, Bulletin entomologique, CCX, CCXI.

Longair RW (1987) Mating behavior at floral resources in two species of Pseudomasaris (Hymenoptera: Vespidae: Masarinae). Proceedings of the Entomological Society Washington 89: 759-769.

Mauss V (2006) Observations on flower association and mating behaviour of the pollen wasp species Celonites abbreviatus (Villers, 1789) in Greece (Hymenoptera: Vespidae, Masarinae). Journal of Hymenoptera Research 15: 266-269. doi: 10.3897/jhr.31.4235

Mauss V (2013) Description of Celonites andreasmuelleri sp. n. (Hymenoptera, Vespidae, Masarinae) from the Middle East with a key to the Palaearctic species of the C. abbreviatus-complex of the subgenus Celonites s.str. Journal of Hymenoptera Research 31: 79-95. Meikle RD (1977-1985) Flora of Cyprus, Volume 1-2. London.

Meteorological Service (2014) The Climate of Cyprus. http://www.moa.gov.cy/moa/MS/ MS.nsf/DMLcyclimate_en/DMLcyclimate_en?OpenDocument [retrieved 4 January 2014]

Müller A (1996) Convergent evolution of morphological specializations in Central European bee and honey wasp species as an adaptation to the uptake of pollen from nototribic flowers (Hymenoptera, Apoidea and Masaridae). Biological Journal of the Linnean Society 57: 235-252. doi: 10.1111/j.1095-8312.1996.tb00311.x

Neff JL, Hook AW (2007) Multivoltinism and usage of multiple nest substrates in a West Texas sand dune population of Pseudomasaris phaceliae Rohwer (Hymenoptera: Vespidae: Masarinae). Journal of Hymenoptera Research 16: 266-276.

Neff JL, Simpson BB (1985) Hooked Setae and Narrow Tubes: Foretarsal Pollen Collection by Trimeria buyssoni (Hymenoptera: Masaridae). Journal of the Kansas Entomological Society 58: 730-732.

Richards OW (1962) A revisional study of the masarid wasps (Hymenoptera, Vespoidea). British Museum (Natural History), London, 294 pp. 
Richards OW (1984) Insects of Saudi Arabia. Hymenoptera: Fam. Masaridae (the Arabian species). Fauna Saudi Arabia 6: 413-422.

Romeis B (1989) Mikroskopische Techniken, 17th ed. Urban und Schwarzenberg, Wien.

Schremmer F (1959) Der bisher unbekannte Pollensammelapparat der Honigwespe Celonites abbreviatus Vill. (Vespidae, Masarinae). Zeitschrift für Morphologie und Ökologie der Tiere 48: 424-438. doi: 10.1007/BF00408580

Torchio PF (1970) The ethology of the wasp Pseudomasaris edwardsii (Cresson), and a description of its immature forms. Contributions in Science Natural History Museum of Los Angeles County 202: 1-32.

Tutin TG, Heywood VH, Burges NA, Valentine DH, Walters SM, Webb DA (1964-1980) Flora Europeae, Volume 1-5. Cambridge.

Weinstein A (2008) No title [photograph of Celonites fischeri at Echium taken in Israel, Tel Aviv env.]. http://www.hymis.eu/gallery/fotos/popups/pictures.php?sub=no\&page=0\&IDs=20 251\&total $=1 \&$ level=3 [retrieved 4 January 2014]

Westrich P, Schmidt K (1986) Methoden und Anwendungsgebiete der Pollenanalyse bei Wildbienen (Hymenoptera, Apoidea). Linzer biologische Beiträge 18: 341-360. 